Prof. dr. Muharem Štulanović

\title{
Žena i nemoral u Šerijatu sa etno-sociološkim osvrtom
}

Sažetak

Kur'an kao Allahova posljednja Objava ljudima takvog je sadržaja da svojom božanstvenošću, nadnaravnošću, svojim čudima koja se očituju i najkraćom surom, svjedoči da ga nije mogao napisati i izmisliti niko drugi osim Uzvišenog i Sveznajućeg Allaha, jer nije bio $u$ stanju, pošto mu'džize $i$ čuda, nadnaravnosti $i$ božanstvenost Kur'ana, te informacije koje se nalaze u njemu nauka i svijet otkrivaju tek u novije doba.

Ta nadnaravna dimenzija Kur'ana tretira se posebno od 1400 h. g., odnosno 1979. g po miladu, kada je osnovano jedno tijelo pri Univerzitetu u S. Arabiji koje će se baviti naučnim proučavanjem Kur'ana.

Pošto je Kur'an osnovni izvor Šerijata onda i njegove norme, ibadeti (obredosovlje) imaju svevremenu aktualnost, svrhovitost, mudrost $i$ nadnaravan božanski karakter. Sve ibadetske aktivnosti nekom svojom funkcijom služe za dobrobit čovjeka da bi ga fizički $i$ duhovno održale u životu na dunjaluku, spasile na ahiretu $i$ bile orjentir jednog normalnog uravnoteženog načina života.

Pojavom islama promijenjen je i poboljšan status žene $u$ dotašnjim vladajućim pravnim običajima, jer islam vrednuje ženu kao „najveće i najvrednije dunjalučko blago" što je revolucionarni napredak u tretmanu žene, daje joj se pravo vlasništva i nasljeđivanja $i$ one se u tom smislu izravnavaju sa muškarcima pa čak dobivaju $i$ diskreciono pravo mehra, kao nagradu ili jedan vid materijalne sigurnosti ulaska u brak što govori o visokoj vrijednosti božanskog sistema Šerijata pošto ove vrijednosti nisu poznavali mnogi pravni sistemi ni hiljadu godina poslije pojave islama. Tako je bilo stanje i sa našim krajevima.

U savremeno doba stižu informacije o nekim novim zakonskim rješenjima koje uvode zemlje kao što su Njemačka i Italija, a s kojima se hoće suzbiti seksualno uznemiravanje žena i mobing u savremenom društvu i radnom okruženju, ali ta zakonska rješenja kao da su 
prepisana iz normi Kur'ana. Dakle zakonodavstvo najvećih ekonomskih zapadnih sila kaska za Kur'anom preko 1400 godina.

Neke aspekte nemorala naglasio je Allahov Poslanik, a.s., kroz hadis kao vid predskazanja koje se ostvarivalo kroz historiju $i$ ostvaruje se u našem vremenu, a ostvaruje se i prijetnja o navještenoj kazni iz pomenutog hadisa i kur'anskih kazivanja o ranijim narodima.

Islam i njegov šerijatski sistem su posebno na meti zbog kazne bluda, tzv. kazne hadda (fiksirana kazna), koja je često predmet neopravdane kritike, averzije i totalnog nerazumijevanja iako je Šerijat posvetio ovom pravnom problemu neprevaziđene, iznijansirane propise i prevenciju, koji štite ljudsko društvo, pravdu pa i aktere samog ovog čina. Sankcija bluda u Šerijatu, kad se sagleda iz svih aspekata, više je preventivne nego retributivne prirode. Problematiku bluda i nemorala može se pratiti i kroz etno-sociološku prizmu, kroz običaje muslimana naših područja i njihovu tradiciju.

Iz svega ovog proizilazi da su islam kao vjera-religija i Šerijat kao njegov pravni sistem nadnaravnog, božanskog karaktera. Ta karakteristika ih odlikuje nad svim ostalim ljudskim sistemima $i$ porecima. To je najbolji mogući sistem življenja za čovjeka $u$ vremenskom totalitetu dunjaluka i ahireta.

\section{Uvod}

Vjera je došla kao univerzalna korist ljudskom rodu kako bi uredila, organizirala i uravnotežila ljudski život. Dragi Allah nema nikakvu potrebu za našom vjerom, kurbanom, žrtvom, sadakom, namazom, hadždžom niti bilo kojom drugom ibadetskom aktivnošću.

Međutim, sve ove aktivnosti nekom svojom funkcijom služe za dobrobit čovjeka. Ustvari, vjera je objavljena upravo da bi muslimane fizički i duhovno održala u životu na dunjaluku, spasila na ahiretu i bila orijentir jednog normalnog uravnoteženog načina života. Time postaje smisao i svrha življenja kao što to Kur'an i konstatuje:

$$
\text { وما خلقت الجن والإنس إلا ليعبدون }
$$

\section{„Nisam stvorio ljude i džine osim da bi obožavali.”}


Propisi islama, njegove norme, ibadeti (obredosovlje) imaju svevremenu aktualnost, svrhovitost, mudrost i nadnaravan božanski karakter.

I to se može zapaziti kod jednog ozbiljnog naučnog pogleda i pristupa $u$ razumjevanju vjere $i$ njenih sastavnih ibadetskih (obredoslovnih) aktivnosti.

Onaj ko ne boluje od predrasuda lahko će uočiti čuda, nadnaravnosti u različitim aspektima Islama kao doktrine i Šerijata kao njegovog pravnog sistema ili poretka.

Kur'an, kao Allahova posljednja Objava ljudima, takvog je sadržaja da svojom božanstvenošću, nadnaravnošću, svojim čudima koja se očituju i najkraćom surom, svjedoči da ga nije mogao napisati i izmisliti niko drugi osim Uzvišenog i Sveznajućeg Allaha, jer nije bio u stanju, pošto mu'džize i čuda, nadnaravnosti i božanstvenost Kur'ana, te informacije koje se nalaze u njemu nauka i svijet otkrivaju tek u novije doba.

Ta nadnaravna dimenzija Kur'ana tretira se posebno od $1400 \mathrm{~h}$. g., odnosno 1979. g. po miladu, kada je osnovano jedno tijelo pri Univerzitetu u S. Arabiji koje će se baviti naučnim proučavanjem Kur'ana.

1423. h. ili 2002. ovo je tijelo nazvano: Svjetski komitet za naučno proučavanje božanstvenosti, nadnaravnosti $i$ čuda Kur'ana $i$ sunneta, i do sada je održalo devet internacionalnih kongresa. Stotine naučnika dostavi svoje referate na temu čuda i nadnaravnosti Kur'ana, a onda se izabere 80- tak za javnu prezentaciju i Kongres.

Zvukovna, glasovna i jezička dimenziju nadnaravnosti Kur'ana je u samom početku Objave uzrokovala potpunu prekretnicu $u$ džahilijetskom vremenu i džahilijetskom društvu.

A kakvo je bilo društvo i vrijeme džahilijjeta?

To je bilo društvo i vrijeme koje se trebalo i moralo mijenjati jer su u njemu postojali mnogobrojni vidovi nemorala i izopačenosti od nepravde, zuluma do ustaljivanja paganskih običaja zakopavanja žive ženske djece.

Arapi su u vrijeme Objave Kur'ana bili na veoma visokom stepenu pjesničkog izražaja. Međutim, oni koji još nisu bili primili 
islam, u susretu sa recitiranim Kur'anom ostajali su u nevjerici, iznenađeni, frapirani. Mogli su samo konstatirati da tako nešto nikad ranije nisu čuli i da to, jednostavno, nije ljudski govor. Njegov sadržaj i informacije koje donosi prevazilaze ljudske mogućnosti. On ima takav nadnaravni, neponovljivi stil koji ga odlikuje nad svim pjesništvom koje je bilo poznato odranije.

Mekanski plemići, aristokrati, prvaci i uglednici, krijući se jedan od drugoga, dolazili su slušati učenje Kur'ana koje je naglas izvodio Poslanik, a.s., klanjajući kod Kjabe. Bilo ih je stid jedni drugih da otvoreno, javno slušaju učenje Kur'ana protiv koga su se zdušno i svojski borili i čije su svjetlo pokušali ugasiti i uništiti. Kur'an ih je jednostavno opčinjavao, iako to nisu htjeli priznati. Tek kada bi poslije primili islam, otkrivali bi šta se zbivalo s njima dok su kao nemuslimani slušali njegovo učenje. Kur'an je kao Allahova riječ i nenadmašni božanski sistem, od ovakvih džahilijjetskih ljudi, iskovao najplemenitije i najčasnije ashabe.

\section{Šerijat kao nedostižni pravni sistem u rješavanju ženskog pitanja}

Uzvišeni Bog objavio je i poslao čovječanstvu pravni sistem Šerijata da ga primjenjuje i sprovodi u praksu. I On najbolje zna šta odgovara čovjeku i šta je najbliže pravdi.

O Šerijatu vladaju pogrešne predrasude kao o sistemu koji je obespravio ženu.

Isto tako poznata su nam i savremena stajališta o ženi koja se nastoji emancipirati. Međutim, u toj prividnoj emancipaciji ona je izigrana, obmanuta, jer joj se želi podvaliti i obezvrijediti je. Naime, emancipacija žena ide u pravcu izjednačavanja s muškarcem u teškim poslovima, u teškim fizičkim obavezama, a u isto vrijeme svodi se na robu koja se može kupiti kao što se kupuje kilogram šećera, kahve, banana.

U ovoj eri, tzv., slobode, ona se može kupiti, razgolićena i potpuno obezvrijeđena, spuštena na nivo potrošne robe tako da se kupuje „kilogram" pornografije, žensko tijelo itd. Zar je to emancipacija?!

Zašto žene pristaju na takav vid ponižavanja i obezvređivanja? 
Zašto se žene ne pobune protiv iskorištavanja njihovog tijela $\mathrm{u}$ svrhu zabave, industrije pornografije i sl.?

Zašto žene i ženska udruženja ne štite svoj ženski integritet, integritet žene-majke, žene koja ima i drugih vrijednosti, a ne samo tijelo? Zašto se ne bore protiv pornografije na elektronskim medijima i filmu, ili protiv slika i statua golih žena koje se javno izlažu pa i kao simboli nekih gradova?!

Kojom logikom se vrednuje i brani nemoral, govoreći da je to umjetnost?!

Ako neko smatra da je skidanje i ekshibicionizam javno pred svima i pred kamerama vrijednost pa da li bi pristao da mu mati ili žena ili sestra ili kćerka, hodaju gole po ulici, pojave se razgolićene pred kamerama i sl.?

Položaj žene $u$ islamu je izuzetno povoljan i povlašten. Pojavom islama revlucionarno je promijenjen i poboljšan dotadašnji status žene. Neke intelektualke iz Njemačke, u svom proučavanju istinskih, realnih vrijednosti položaja žene u islamu i komparirajući to sa lažnom emancipacijom žene na Zapadu primile su islam želeći da se koriste tim povlaštenim položajem koji islam daje ženi kao Allahovom stvorenju.

Da se razumije kako islam gleda na ženu dovoljno je samo navesti nekoliko citata Poslanika, a.s, koji govore o vijednosti žene:

Muslim bilježi od Amr b. El-A'sa da je Poslanik, a.s., rekao:

$$
\text { الدنيا متاع وخير متاعها المرأة الصالحة }
$$

Dunjaluk je uživanje i naslada, a njegova najveća vrijednost je poštena žena. rekao:

Ebu Davud bilježi od Ibni Abbasa, r.a. da je Poslanik, a.s.,

$$
\text { ألا أخبر كم بخير ما يكنز المرأة الصالحة إذا نظر إليها سرته وإذا غاب عنها خفظته و إذا أمرها }
$$

Hoćete li da vas obavijestim o blagu koje se čuva. Poštena žena koju čovjek kada pogleda obraduje ga, kada je ostavi čuva mu čast i obraz, i kada joj naredi pokori mu se. 
Tirmizija i Ibni Madždže bilježe da su ashabi na jednom putovanju, nakon što je objavljen ajet koji govori o zabrani gomilanja zlata i srebra, a da se ne daje zekjat, rekli:

$$
\text { .... فلو علمنا أي المال خير فنتخذه؟ ... فقال: لسان ذاكر، وقلب شاكر، وزوجة مؤمنة تعينه }
$$

...Da nam je znati koji imetak i koja vrijednost je najvrednija pa da to štedimo i gomilamo?" Poslanik, a.s. je rekao: „To je jezik koji zikrom zbori, srce koje je zahvalno i žena vjernica koja je oslonac u vjerovanju."

Eto, tako islam vrednuje ženu kao „najveće $\boldsymbol{i}$ najvrednije dunjalučko blago" što je revolucionarni napredak tretmana žene u dotašnjim vladajućim pravnim običajima. Dakle, islam daje prava ženi mijenjajući njen dotadašnji položaj i status na bolje, jer je u tom džahilijetskom vremenu i džahilijetskom društvu bio nezavidan, a ona obespravljena u takvom omjeru da su predislamski Arapi bili ustrojili paganski običaj zakopavanja žive ženske djece, prakticiran kod mnogih sve do pojave Muhammeda, a.s., koji je od Allaha, Gospodara kosmosa, Gospodara Zemlje i nebesa poslan da to zabrani.

U tefsiru Ibn Kesira navodi se slučaj Kajs ibn Asima koji je došao Allahovom Poslaniku, a.s., i rekao: „Allahov Poslaniče, u džahilijjetu sahranio sam osam živih djevojčica.“1

Kakvo čudovište može biti čovjek, i kakvo to kameno srce može zakopati svoje živo dijete samo zato što nije sin koji može uzeti sablju i ratovati?

Kur'an ovaj ružni običaj spominje kroz dva ajeta, koji su toliko upečatljivi, da ništa više nije objavljeno u Kur'anu bilo bi dovoljno da se uzvjeruje u Dragog Allaha i prihvati Kur'an kao istina.

Uzvišeni Allah opisujući strahote zemaljskog i kosmičkog kolapsa i meteža na Sudnjem danu dalje kaže:

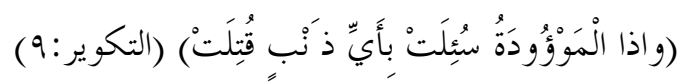

\footnotetext{
${ }^{1}$ Muhammed Nesib Er-Rifa'i, Tefsir Ibn Kesir, skraćeno izdanje, (Sarajevo, 2000), 1476.
} 


\section{I kada živa sahranjena djevojčica bude upitana, zbog kakve krivice je umorena.../Et-Tekvir:8-9/}

U božanskom izrazu: - I kada živa sahranjena djevojčica bude upitana - upotrijebljen je pasiv u značenju da će umorena, nevina, bezgrješna djevojčica biti pitana.

Poznato je, psihološki, da se nevin čovjek, kao i čovjek koji traži svoje pravo na sudu, nelagodno osjećaju iako potražuju svoje pravo, jer na sudu bivaju pitani i saslušavani.

Prema tome, kada je činjenica da će i umorena, nevina, bezgrješna djevojčica biti ,pitana i saslušavana“, pa kako će tek biti situacija s onima koji su ih bespravno ubijali. Ovakav kur'anski izraz je, ustvari, prijetnja koja se izražava na ovakav implicitan, mefaforičan, božanski nenadmašan način.

\section{Žena i pravo nasljeđivanja}

U predislamsko, džahilijetsko doba žena je bila obespravljena u svakom pogledu. Između ostalog, njeno pravo vlasništva bilo je narušeno pravom skrbnika-staratelja koji je mogao slobodno raspolagati $\mathrm{s}$ njenom kompletnom imovinom. Pojavom islama dokidaju se takvi pravni običaji, a ženama se daje pravo vlasništva i nasljeđivanja i one se u tom smislu izravnavaju sa muškarcima ${ }^{2}$.

I ne samo to, nego islam ide i dalje pa daje ženi diskreciono pravo mehra, kao nagradu ili jedan vid materijalne sigurnosti ulaska $\mathrm{u}$ brak, kao i pravo nasljeđivanja, što govori o visokoj vrijednosti božanskog sistema Šerijata.

Te vrijednosti nisu poznavali mnogi pravni sistemi ni hiljadu godina poslije pojave islama. Tako je bilo stanje i sa našim krajevima.

Mnogi ne znaju da je žena i u našim krajevima bila obespravljena i hiljadu godina nakon što ju je oslobodio islam.

Tek dolaskom islama u Bosni i Hercegovini, šerijatsko zakonodavstvo utječe da se obespravljena žena izjednači sa

\footnotetext{
${ }^{2}$ Da ne bi bilo zabune kod onih koji čitaju između redaka, žena i muškarac nemaju iste alikvotne nasljedne dijelove
} 
muškarcem u pravu nasljeđivanja za koje je ona bila prikraćena običajnim pravom, a posebno u domenu nasljeđivanja nekretnina.

Dr. Vojislav Spaić raspravlja o utjecaju šerijatskog prava na nasljednopravne običaje u Bosni i Hercegovini u svojoj doktorskoj disertaciji pod naslovom Nasledno običajno pravo u BiH, koja je odbranjena 22. marta 1941. godine na Pravnom fakultetu u Beogradu, a 1967. godine, objavljuje vrijednu naučnu studiju pod naslovom Nasljednopravni običaji u BiH nakon Austro-Ugarske okupacije, u zbirci Radovi Akademije nauka i umjetnosti Bosne i Hercegovine. ${ }^{3}$

U ovoj studiji, prof. Spaić daje integralni tekst Projekta nasljednog zakona, koji je urađen prije Drugog svjetskog rata, ali nikad nije ozakonjen.

On navodi o nasljeđivanju žena: “... pa se, s potpunim pravom, može reći da su žene bile isključene iz nasljeđivanja nekretnina. Osim toga, ne smijemo zaboraviti da su ovi pravni običaji koji dozvoljavaju ženama nasljedstvo vlastite zemlje nastali pod utjecajem turskog zakonodavstva."

Dakle, kao što se razumije iz ove naučne studije dr. Spaića, žena je u našim krajevima tek pod utjecajem šerijatskog zakona, dolaskom islama i primjenom Šerijata na ovim prostorima dobila svoje pravo nasljeđivanja.

\section{Mobing i seksualno iskorištavanje}

U savremeno doba globalizacije i demokratskih pokreta i procesa ne iznenađuje činjenica da sredstva informiranja ${ }^{5}$ donose informacije o nekim novim zakonskim rješenjima koje uvode zemlje kao što su Njemačka i Italija s kojima se hoće suzbiti seksualno uznemiravanje žena i mobing u savremenom društvu i radnom okruženju, ali prosto frapira činjenica da ta zakonska rješenja kao da su prepisana iz normi Kur'ana. Dakle, zakonodavstvo najvećih

3 Vidi, Vojislav Spaić, Nasljednopravni običaji u BiH nakon Austro-Ugarske okupacije, Akademija nauka i umjetnosti BiH, knjiga XXXII., Odjeljenje društvenih nauka, knjiga 11., Sarajevo, 1967.

${ }^{4}$ Ibid., 64. Vidi, također, o utjecaju turskog zakonodavstva, str. 61.

${ }^{5}$ Dnevni avaz, 28 februara 2008. 
ekonomskih zapadnih sila kaska za Kur'anom preko 1400 godina. U Kur'anu se kaže:

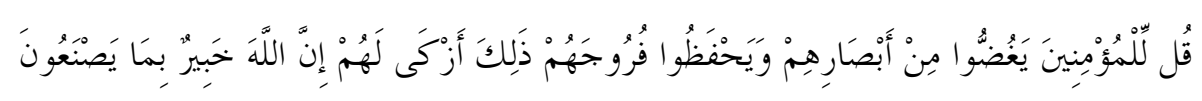

„Reci vjernicima neka obore poglede svoje i neka čuvaju stidna mjesta svoja; to im je najčednije, jer Allah, uistinu, zna ono što oni rade.“ (En-Nur, 30.)

Ebu Davud prenosi od Burejde da je Allahov Poslanik s.a.v.s. rekao Aliji: "Ne bacaj pogled za pogledom, imaš pravo na prvi, ali ne i na drugi."

Isto se tako naređuje i vjernicama:

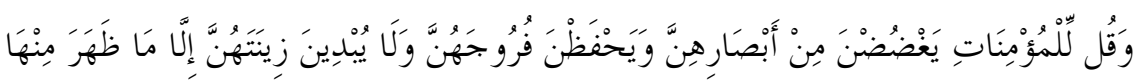

„A reci vjernicama neka obore poglede svoje i neka čuvaju stidna mjesta svoja; i neka ne pokazuju ukrase svoje osim onoga što je ionako spoljašnje..." (En-Nur, 31.)

U Italiji su izglasali zakon koji je kopija Njemačkog, a u kojem je usvojeno da:

Novi zakonski normativ po kojem žene imaju pravo tužiti $i$ tražiti visoke odštete za duži pogled kolege u njenom smjeru.

Novi zakonski dekret je jedna vrsta prevencije od seksualnog uznemiravanja na radnom mjestu.

... predviđene su najteže kazne za fizičke dodire...Svaki fizički dodir pa čak i rukovanje... norme?!

Zar ova rješenja ne podsjećaju na spomenute kur'anske

Zašto smo rekli da ova zakonodavstva kasne i kaskaju za šerijatskim?

Iz razloga što neodoljivo podsjećaju na spomenute norme $\mathrm{i}$ propise izvedene iz svetih tekstova Kur'ana, ali u smislu adresata kojima se upućuju odnose se samo na radno okruženje i zaštitu žena, kao „slabijeg spola" na poslu. Dakle, radi se samo o ograničenom, 
jednostranom rješenju i pokušaju zaštite samo ženske populacije i samo u radnom okruženju, gdje je najnezaštićenija.

Nadalje, ova zakonodavstva ne propisuju pokrivanje kao sredstvo koje može pridonijeti zaštiti, nego dozvoljavju otkrivanje i pokazivanje dijelova tijela što je eksplicitni ,poziv" na mobing i uznemiravanje.

A kur'anske norme su općenite i ne ograničavaju se samo na poslovno okruženje, nego obuhvataju društvo u svim njegovim sferama i djelatnostima, i ne samo da se odnose na zaštitu ženske nego i muške populacije, kao što se razumije iz spomenutih kur'anskih normi, pa čak rješavaju odnose roditelja $\mathrm{i}$ njihove djece unutar njihovih porodičnih stanova.

"O vjernici, neka od vas u tri slučaja zatraže dopuštenje da vam uđu oni koji su u posjedu vašem i oni koji još nisu spolno zreli: prije jutarnjeg namaza i kada u podne odložite odjeću svoju, i poslije obavljanja noćnog namaza. To su tri doba kada niste obučeni, a u drugo doba nije ni vama ni njima grijeh, ta vi jedni drugima morate ulaziti. Tako vam Allah objašnjava propise! A Allah sve zna i Mudar je. A kad djeca vaša dostignu spolnu zrelost, neka onda uvijek traže dopuštenje onih starijih od njih; tako vam Allah objašnjava propise Svoje! A Allah sve zna i Mudar je." (En-Nur, 58-59.)

I ne samo da Šerijat daje kompletna rješenja, nego čak i prevenciju. Konvencionalna i savremena zakonodavstva dozvoljavaju pornografiju, ekshibicionizam, nepristojno, izazovno oblačenje ili razgolićenost, što je upravo poziv na nemoralnost.

Nasuprot toga, šerijatsko zakonodavstvo propisuje oblačenje i pristojnost kao najpraktičnije sredstvo za zaštitu od mobinga i seksualnog iskorištavanja.

Kur'an je od Dragog Boga, Njegova milost ljudima i dar da imaju program po kojem će živjeti. To je najbolji mogući sistem življenja za čovjeka u vremenskom totalitetu dunjaluka i ahireta. 


\section{Poslanikova, a.s., nadnaravna navješćenja kazne za nemoral}

Neke aspekte nemorala naglasio je Allahov Poslanik, a.s. kroz hadis kao vid predskazanja koje se ostvarivalo kroz historiju i ostvaruje se u našem vremenu.

Bilježe Ibnu Madždže, Bejhekijja i Bezzar od Ibni Omera, a i Hakim od Burejde vjerodostojno predanje, po kriterijima Muslima, u kojem se kaže:

„Došao nam je Allahov Poslanik, a.s., i rekao:

\section{„Muhadžiri!}

Sa pet svojstava, ako se nađu pri vama, bićete iskušani,-a ja se utječem Allahu moleći Ga da vi to ne dočekate-:

- nikada se neće pojaviti razvrat u nekom narodu koji ga bude javno činio, a da se paralelno s tim ne prošire kuga i bolesti potpuno nepoznate ranijim, prošlim generacijama'.",

U verziji ovog predanja koje bilježi Malik, navodi se:

,...niti će se proširiti zinaluk (prostitucija) u nekom narodu, a da se paralelno s tim ne proširi i poveća smrtnost."

Hadis baca težište na dvije bitne stvari iz kojih proizilazi i ovosvjetska i onosvjetska kazna, a to su:

1. pregonjenje u griješenju do razvrata $i$

2. javno ponavljanje grijeha.

\section{Razvrat}

Razvrat, spomenut u hadisu, islamski učenjaci prokomentirali su prostitucijom, homoseksualizmom i drugim vidovima perverzije koja se javno i bestidno upražnjava. U današnje vrijeme svi smo svjedoci da se to javno dešava. I to je tako odvratno i odurno da pamet stane kad se čuje ili vidi kakve se sve nepodopštine javno događaju.

\footnotetext{
6 Vidi, Zekijjud-din El-Munziri, Et-Tergibu vet-terhibu minel-hadisiš-šerif (Stimuliranje i zastrašivanje kroz hadis Allahovog Poslanika a.s.), (Muessesetuttarih vet-turasil-arebi, 1968), 2, 568.

${ }^{7}$ Ibid, 569.
} 
Neke od njih su, umjesto da budu sankcionirane, zaštićene kao zakonske i legalne u najrazvijenim zemljama svijeta, koje očito idu u moralni, ali ne samo moralni kolaps. Tako je legalizovan brak lezbijki i homoseksualaca u nekim zapadnim zemljama, a dozvoljen je i kod nas zakonom koji nam uvezoše stranci i natjeraše na usvajanje. Upražnjavaju se vanbračni seksualni odnosi kao normalna pojava pa čak i seksualni odnosi i brak sa životinjama.

Mogli smo u dnevnoj štampi pročitati bizarnu priču na ovu temu. U Americi su na sudu otac i sin. Otac je optužen za pokušaj ubistva sina, što i nije neki posebno zanimljiv pravni slučaj, jer se tako nešto događa u savremenom društvu ogrezlom $u$ sve vidove izopačenosti.

Pa šta je bilo čudno u ovom konkretnom sudskom slučaju?

Bio je to zahtjev sina da suđenju prisustvuje ,njegova supruga" i odbijanje suda da se udovolji njegovom zahtjevu. Njegova supruga bila je kuja s kojom je živio u javno oglašenom braku i zbog čega ga je otac htio i ubiti. Pošto je njegova ,zakonska supruga“ bila keruša, sud je obrazložio da zakon dozvoljava prisustvo u sudnici samo pasa koji su vodiči slijepih ljudi, a ne i kuja ili kerova koji su u ulozi bračnog druga.

Do ruku mi je dospjelo i jedno javno istraživanje-anketa o seksualnom životu 1000 ispitanika (žena i muškaraca) u Hrvatskoj čiji su rezultati $i$ zaključci javno objavljeni u sredstvima javnog informiranja. ${ }^{8}$

U toj anketi se navodi, između ostalog, da $40 \%$ ispitanika opći u analni otvor; $2 \%$ opći sa životoinjama; svaka deveta žena, u nekim područjima obuhvaćenih anketom, ili čak svaka šesta u drugim područjima, ima iskustva sa osobom istog spola; vanbračni odnosi su gotovo normalni i dostižu procenat od $46 \%$ u pojedinim ispitanim područjima i sl.

Sa islamskog stajališta to je sve vid zabranjene seksualne aktivnosti:

1. Objavljivanje intimnosti seksualnog života zabranjeno je po hadisu koji bilježe Buharija i Muslim:

${ }^{8}$ Vidi, Nacionalni tjednik, Globus, br:702, 21/05/2004. 
„Najgori čovjek stepenom kod Allaha, dž.š., na Sudnjem danu je onaj koji priđe ženi i ona njemu, a potom iznosi njene tajne."

Iz samog hadisa se razumije zabrana prenošenja i opisivanja pojedinosti intimnog odnosa $i$ onoga što se odigra $u$ trenucima uživanja čovjeka sa ženom. Međutim, samo pominjanje odnosa bez nekog opravdanog razloga je mekruh.

2. U islamu je zabranjeno općenje u analni otvor. Haram je imati snošaj u stražnji, analni otvor, kao i u prednji u vremenu menstruacije, ili u periodu nakon porođaja, dok se žena ne očisti i dok ne prođe taj period, zbog ajeta u kome se kaže:

„I ne približavajte se ženama dok su u menstrualnom ciklusu...“

I zbog hadisa koga bilježe autori hadiskih zbirki „Sunnen” (Ebu Davud, Tirmizija i Ibni Madždže) osim Nesaije:

„Ko ima intimni odnos sa ženom, dok je u menstrualnom ciklusu, ili u analni otvor, taj je postao nevjernik u ono što je objavljeno Muhammedu a.s.“

Nesaija bilježi i verziju hadisa:

„Priđi ženi sprijeda ili od pozadi, ali samo u prednji otvor, i ne čini to za vrijeme menstruacije.“

Također, bilježi i drugu verziju: stražnji, analni otvor.“

„Allah ne gleda u čovjeka koji ima odnos sa ženom u

Ebu Davud bilježi hadis:

„Proklet je onaj koji opći sa ženom u analni otvor.“

A Nesaija bilježi predaju:

Ibni Abbas je pitan o onome koji opći sa ženom u analni otvor pa je rekao: „Ovaj me pita o nevjerovanju (kufuru).“

Dozvoljeno je prilaziti ženama u bilo kojoj pozi, ali da snošaj bude u prednji otvor, po ajetu u kome se kaže:

„Vaše žene su njive vaše i prilazite im kako hoćete...“, što je Poslanik, a.s., prokomentirao, kako bilježe Buharija i Muslim: 


\section{otvor." \\ „Sprijeda ili odpozada samo da snošaj bude u prednji}

Osoba za koju se zna da opći sa ženom u njen analni, stražnji otvor, kažnjava se kaznom ta'zira, ako je znao za tu zabranu.

A ako se bračni par oda takvoj perverziji, kažnjavaju se prisilnim razvodom, također i u slučaju ako muž sili ženu na takav odnos pa mu se zabrani, a on to ponovi.

3. Zinaluk je po islamu strogo zabranjen. To će biti predmetom posebne eksplikacije.

4. Također, zabranjeni su lezbejstvo i homoseksualizam. Aktualno pitanje koje se zadnje vrijeme provlačilo kroz medije u našoj javnosti gotovo kao planetarni problem - iako se radi samo o slučaju nekoliko nastranih indivdua - jeste javni pokušaj gay paradiranja u našem bosanskom miljeu, preko čijih neprihvatljivih aktivnosti se htjelo, pod izlikom zaštite ljudskih prava, po ko zna koji put, izvršiti medijski napad i nezapamćena medijska haranga na vjeru i vjerske velikodostojnike, autoritete i učenjake.

O ovom pitanju nema mnogo manevarskog prostora za pametovanje. To je jedan od grijeha i perverznosti na čiji se sami pomen ježi normalan čovjek osjećajući odvratnost i osjećaj povraćanja

Kakav je to grijeh i šta je to, ustvari?

To je jednostavno rečeno veza i parenje dvoje ljudi istog spola nazvan u uličnom žargonu pederluk, a gay parada je trebala taj odnos promovirati $\mathrm{i}$ prikazati normalnim $\mathrm{i}$ savremenim $\mathrm{i} u$ našem „,nedemokratskom društvu".

Šta prouzrokuje i do kojih posljedica dovodi ova nastrana seksualna aktivnost?

Uzročnik je obolijevanje od HIV-a, dovodi do neizlječivih bolesti i pod pretpostavkom da ga prihvati ljudski rod kao svoju praksu nestalo bi ga samo za vrijeme jedne generacije, jer ne bi bilo reprodukcije. Sa generacijom homoseksualaca nestalo bi ljudskog roda.

Svi pravni sistemi imaju sankciju, zatvor i kažnjavanje za prijestupnike. Onaj ko ubije namjerno, bespravno, osuđuje se u svim 
pravnim sistemima. Analogno tome, pitamo se šta zaslužuje onaj koji planira da svojim skončavanjem dočeka kraj svoje ljudske vrste? Šta bi bila presuda za one koji svojim ponašanjem, praktično, te svojim organiziranim djelovanjem, javno pozivaju i snuju zatiranje ljudskog roda $\mathrm{i}$ iskorjenjivanje ljudske vrste? Malo je reći da to treba spriječiti i kao praksu i kao ideju. To je zločin najviše kategorije, treba ga tako kvalificirati i protiv toga se treba boriti, u najmanju ruku primjereno sistemu u kojem se živi i shodno kur'ansko-sunnetskim normama:

- Neki pokušavaju opravdati ili makar blagonaklono gledati prema ovom problemu i njegovim protagonistima.

- Drugi to smatraju sklonošću-bolešću, poremećenom prirodom i s tog aspekta gledaju na problem.

- Treći to gledaju politički, zbog svjetskih lobija koji podržavaju te nastranosti i oni zarad političkih poena taj problem i njegove protagoniste stavljaju u rang demokratije, ljudskih prava i sl.

Bez obzira kako to tretirali: da li kao sklonost, bolest, poriv, poremećenu ljudsku prirodu i sl., sve to u krajnjoj konsekvenci ne daje opravdanje, legitimitet i dozvolu za ovo zlo. I drugi imaju prirodne porive za zinalukom, kao što su neoženjeni zdravi i normalni ljudi, za tuđim imetkom, za tuđom ženom, za tuđim novcem, za tuđim autom i sl. Da li sve to treba dozvoliti pod izlikom ljudskih prava, slobode $\mathrm{i}$ demokratije?!... Od grijeha se treba i mora sustegnuti i kloniti ga se. Tako i od ovog, bez obzira da li je to bolest, sklonost, poremećena priroda ili strast...

A demokratija ne smije ići na uštrb zaštićenih univerzalnih vrijednosti koje su u suprotnosti s ovim grijehom.

Uzvišeni Allah obavještava kako je skončao narod Luta, a.s., koji je kažnjen zbog toga što se odao homoseksualizmu. U Kur'anu se kaže:

„I kada pade naredba Naša, Mi sve prevrnusmo, ono što je gore - bi dolje, i na njih kao kišu grumenje od pečena blata spustismo, koje je neprekidno sipalo, obilježeno od Gospodara tvoga , - a ono nije daleko ni od jednog nasilnika.“ (Hud, 82-83.)

5. Po islamu je zabranjeno i seksualno općenje sa životinjama po konsenzusu uleme. Međutim, ne postoji konsenzus oko vrste sankcija za to djelo. Ahmed, Ebu Davud i Tirmizija bilježe hadis: 


\section{„Onoga ko opći sa životinjom ubijte, a ubijte i životinju.“}

Dakle, prvi dio spomenutog hadisa ili navješćenje Allahovog Poslanika, a.s., o tome da će se ove nemoralnosti događati ostvaruje se danas u vidu javnih bestijalnosti i nepodopština i čak se objavljuju ankete koje to tretiraju i obrađuju, gotovo kao potpuno normalnu pojavu.

Međutim, da li se ostvaruje i prijetnja o navještenoj kazni iz pomenutog hadisa i kur'anskih kazivanja o ranijim narodima?

Bez ikakve sumnje $i$ ona se ostvaruje proporcionalno ostvarivanju prvog dijela hadisa.

Iz same ankete, koju smo spomenuli, razumije se da je vid kazne već stigao. Naime, ta seksualna izopačenost, koja se iskristalizirala u anketi, sigurno je prouzrokovala da tek $27 \%$ osoba, iz nekih područja obuhvaćenih anketom, ili tek $9 \%$, iz nekih drugih, doživljava zadovoljstvo u bračnim odnosima. U nekim drugim područjima $24 \%$ ispitanika rijetko doživljava to zadovoljstvo ili gotovo nikada

Seksualno uživanje kod normalnih ljudi je jedno od najvećih dunjalučkih ni'meta i uživanja. Ako je to tako, onda je i prikraćivanje tog uživanja jedan vid strašne kazne.

Dakle, jedno od najljepših dunjalučkih uživanja velikom procentu ispitanika ankete je prikraćeno. Uzvišeni Allah im je oduzeo to uživanje. Zar to, samo po sebi, nije strašna kazna?!

A da ne govorimo o zastrašujućim spolnim bolestima koje se javljaju kao dunjalučka kazna i odgovor na sve ove seksualne izopačenosti. Ona je navješćena i obećana na jeziku Allahova Poslanika, s.a.v.s., prije 1400. g. jer „,nove nepoznate bolesti““, o kojima govori spomenuti hadis, savremeni učenjaci između ostalog tumače da se odnose na spolne bolesti kao što su sida i druga savremena aktualna virusna oboljenja koja nisu bila poznata ranijim generacijama ${ }^{9}$.

\footnotetext{
${ }^{9}$ O ovoj temi sa šerijatskog aspekta i spolnim bolestima od kojih su: sida, klamidija N. G. U., gonoreja N. G. D., sifilis i druge bolesti, pogledaj u knjizi Spolne bolesti dr. Muhammeda Ali El-Barra, u izdanju Visokog saudijskog komiteta za pomoć BiH, Sarajevo, 1998.
} 
Naravno, ovim navješćenjima Allahovog Poslanika, a.s., nije potreban nikakav poseban komentar. Dovoljno je da se imaju zastrašujuće informacije o oboljelima od side i o progresivnoj smrtnosti onih kod kojih je došlo do inficiranja i zaraze uzrokovane nemoralom i razvratom. Nasuprot toga, u zemljama u kojima se drži do šerijatskih normi i kloni se razvrata, ove bolesti su nepoznate.

Iz ovakvih jednostavnih primjera možemo zaključiti da su islam kao vjera-religija i Šerijat kao njegov pravni sistem, nadnaravni, božanskog karaktera. Ta karakteristika ga odlikuje nad svim ostalim ljudskim sistemima i porecima. Zar mogu ljudi ustrojiti nešto kao što to ustroji Bog?! Nikako!

\section{Javno griješenje i Allahove egzemplarne sankcije}

Javno, kolektivno upražnjavanje zabranjenih radnji povlači i kolektivnu ovosvjetsku kaznu, kao što Kur'an obavještava u primjerima ranijih naroda.

U širokom dijapazonu sankcija, kojima Uzvišeni Allah kažnjava neposlušne robove i narode, nalaze se i dunjalučke (ovosvjetske) masovne kazne egzemplarnog karaktera. Kur'an nam daje primjere drevnih naroda i raznovrsnih kazni koje su ih zadesile zbog njihovih grijeha i neposluha. Narod Ada kaznio je i uništio „vjetrom ledenim, silovitim" ", narod Semuda ,glasom strahovitim”, narod Nuha „potopom”12 općim, narod Luta „kišom grumenja od pečena blata koje je neprekidno sipalo obilježeno od Gospodara tvoga"13 narod Šu'ajba ,glasom užasnim"14 itd. Njegova kazna nije bila nepravedna prema njima, nego u srazmjeri sa grijehom koji su neprestano javno činili.

Ovdje ćemo navesti kroz hermeneutiku Kur'ana i njegovog kazivanja jednu posebnu, specifičnu kaznu koju su doživjeli Jevreji za jedan, također, poseban, jedinstven način griješenja. Naime, oni su

\footnotetext{
${ }^{10}$ Kur'an, 68, 6.

${ }^{11}$ Ibid, 68, 5 i $11,69$.

${ }^{12}$ Ibid, $11,43$.

${ }^{13}$ Ibid, 11,82 .

${ }^{14}$ Ibid, $11,94$.
} 
zbog pokušaja hile ${ }^{15}$, nadmudrivanja Allaha, dž.š. i izigravanja Njegovih propisa, egzemplarno i drakonski kažnjeni jedinstvenom neponovljivom kaznom na ovom svijetu.

U Kur'anu se navodi primjer drevnog židovskog naroda koji se služio trikovima $i$ hilama $u$ pokušaju preinačavanja prirode zabranjenih djela „čineći ih dozvoljenim” pa su zbog toga kažnjeni neuobičajenom, strašnom kaznom pretvaranja u majmune ${ }^{16}$.

„Vama je poznato ono što se dogodilo onima od vas koji su se o subotu ogriješili, kao i to da smo im Mi rekli: ,Budite majmuni prezreni..""17

Iz hermeneutike ovoga ajeta saznajemo da su Židovi odbili dan džume kao odabrani praznični dan tražeći umjesto njega da to bude subota. Petak je bio obavezan praznični dan kroz historiju za sve narode prije židovskog, kao i za muslimane poslije njih. Pošto su oni odbili petak insistirajući da praznik bude subotom, onda ih je Allah, dž.š., iskušao nečim što im je inače dozvoljeno, tj. zabranom lova $\mathrm{i}$ jedenja ribe na dan svetkovanja, subotom. Međutim, jata velikih riba (kitovi), Allahovom odredbom, dolazila su do obale samo subotom. Dakle, ribe je bilo u izobilju odabranim neradnim danom, kada je Židovima bilo zabranjeno loviti i jesti ribu. Drugim, radnim danima, kada su smjeli loviti, ribe nije bilo ni za lijeka. Povlačila se negdje na pučinu tako da je više nisu ni viđali do subote.

U Kur'anu se kaže: „I upitaj ih o gradu koji se nalazio pored mora kad su propise o suboti kršili: kad su im ribe, na oči njihove, dolazile dok su subotu svetkovali, a kad nisu svetkovali one im nisu dolazile. Eto, tako smo ih u iskušenje dovodili zato što su stalno griješili." 18

\footnotetext{
15 Kratka pravno-šerijatska definicija hile je: „Dospijevanje sa uzakonjenim do onoga što nije dozvoljeno, ili to je ono što (formom) liči na dozvoljeno, a nedozvoljeno je".

Vidi: dr. Muhammed Revas Kal'atdži, dr. Hamid Sadik Kanibi, Mu'džemu lugatilfukaha'i, a'rebi- inklizi (Arapsko-engleska enciklopedija šerijatsko-pravne terminologije), (Darun-nefais, 1985), korijen: hiletun, 188.

16 Vidi, Muhammed b. Ahmed El-Kurtubi, El-Džamiu' liahkjamil-Kur'an, (Zbornik propisa Kur'ana), (Daru ihjait-turasil-Arebi, Bejrut, Libanon, 1985) 1, 331.

${ }^{17}$ Kur'an, 2, 65.

${ }^{18}$ Ibid, $7,163$.
} 
$\mathrm{Na}$ koncu nisu izdržali iskušenje pa su počeli pojedinačno smišljati trikove kako da zadrže i love ribu subotom, a u isto vrijeme izbjegnu skrnavljenje zabrane lova. Praktično je to započelo u naselju Medjena kada je neki čovjek ulovio kita subotom, svezao ga za kolac poboden na obali, a zatim pustio u vodu. U nedjelju ga je izvadio i ispržio. Tom hilom je htio izigrati propis zabrane lova subotom. Tako je učinio i slijedeće subote. Komšiluk je osjetio miris pržene ribe i taj trik se otkrio. Tako su i ostali počeli sa istim poslom ,tajno” i to je trajalo dugo vremena. Allah, dž. š. ih nije kažnjavao sve dok to nisu počeli javno raditi i javno prodavati ulovljenu ribu na tržnici.

Drugi se poslužio još originalnijim trikom. Iskopao je rupu na obali do koje je prokopao jarak. Za vrijeme plime valovi bi donijeli ribu u tu rupu. Kada bi se voda povukla jarkom, riba bi ostajala zarobljena i ne bi se mogla vratiti na pučinu. ${ }^{19}$

Kada je kršenje zabrane postalo javno ${ }^{20}$ i masovno, njihova ulema ih je počela upozoravati na grijeh zabranjujući im takve trikove. Židovi su odbili da prestanu sa lovom, braneći se kako love i vade ribu iz vode nedjeljom tj, dozvoljenim danom.

Oni koji nisu činili taj grijeh podijelili su se na dvije grupe: opominjači i neutralci. Neutralci su govorili kako to Kur'an bilježi:

\section{„A kad neki od njih rekoše: ,Zašto opominjete narod koji će Allah uništiti ili ga teškim mukama namučiti?'- oni odgovoriše: ,Da bismo se pred Gospodarom vašim opravdali i da bi se oni grijeha klonili.","21}

Nakon toga su se podijelili. Vjernici su se odvojili u jednom dijelu naselja pregradnim zidom i posebnim gradskim vratima, ne miješajući se sa onima koji nisu svetkovali subotu. Davud, a.s., ih je prokleo. Kur'an dalje konstatira:

\footnotetext{
19 Ibid.

${ }^{20}$ Iz kur'ansko-sunnetskih normi, a i iz iskustva, zna se da Allah, dž.š. ne trpi javno griješenje i pregonjenje u griješenju i zulumu (nasilje). Kada ono postane opće, javno griješenje na ulici, bez stida i bojazni od kazne, i kada se izgubi nada $u$ popravljanje i kajanje, onda Allah, dž.š. interveniše sa dunjalučkom, kolektivnom kaznom koju požuri spuštajući je na grješni narod u vidu raznih katastrofa, kataklizmi, u vidu ranije nepoznatih bolesti i sl, kako bi se iza toga nastavila $\mathrm{i}$ eshatološka kazna.

${ }^{21}$ Kur'an, 7, 164.
} 
„I kad zaboraviše ono čime su bili opominjani, Mi izbavismo one koji su od nevaljalih djela odvraćali, a teškom kaznom kaznismo grešnike, zato što su stalno u grijehu bili. I pošto su oni bahato odbili da se okane onoga što im se zabranjivalo, Mi smo im rekli: ,Postanite majmuni prezreni!",22

Jedno jutro vjernici su izašli vani, međutim, nevjernici nisu otvarali svoja vrata. Popeli su se na zid i ugledali ih pretvorene u majmunski čopor. Otvorili su im vrata i oni su se razišli po zemlji. ${ }^{23}$

U sažetku tefsira (komentara) Ibnu Kesira spominje se da su Židovi istinski pretvoreni u majmune i nisu živjeli poslije toga više od tri dana, ne jedući, ne pijući i seksualno se ne približavajući ženama. ${ }^{24}$

U hermeneutici ovoga ajeta spominje se i mišljenje Mudžahida koji smatra da je ajet, ipak, samo metafora o pretvaranju Židova u majmune $^{25}$.

Dakle, u ovom kur'anskom primjeru vidimo da se lukavštinom i trikom ne mijenja status i priroda zabranjenog djela, naprotiv, i pokušaj toga kažnjava se najstrožijom kaznom. Naravno, to što su Židovi lovili u zabranjeni dan i prolijevali riblju krv nije bio veći haram od prolijevanja ljudske krvi i krvi poslanika koje su ubijali, te krvi palestinskih civila, djece žena i staraca.

Pa ipak, Kur'an obavještava da je Allah, dž.š., požurio sa ovosvjetskom kaznom prvih, pretvarajući ih u majmune, dok je drugima odložio kaznu za budući svijet. Međutim, u tome ima simbolike. Židovi koji su činili taj prijestup bili su sljedbenici Tevrata (Tore) pretvarajući se da slušaju i poštuju njegove norme, iako su u stvari činili prekršaj. Taj pokušaj izigravanja propisa samo je ličio na pokornost i poštivanje normi, a u biti je bio nedozvoljen čin. Zato je i

\footnotetext{
${ }^{22}$ Ibid, 7, 165-166.

23 Vidi, Muhammed b. Ahmed El-Kurtubi, El-Džamiu' liahkjamil-Kur'an, (Zbornik propisa Kur'ana), (Daru ihjait-turasil-Arebi, Bejrut, Libanon, 1985) 1, 332. ${ }^{24}$ Muhammed Nesib Er-Rifa'i, Tejsirul-Alijjil-kadir lihtisari tefsir Ibn Kesir, (Olakšavanje Uzvišenog-Moćnog u sižeiranju komentara Ibn Kesira), (Bejrut, 1978), 1,64 .

25 Vidi, Muhammed b. Ahmed El-Kurtubi, El-Džamiu' liahkjamil-Kur'an, (Zbornik propisa Kur'ana), (Daru ihjait-turasil-Arebi, Bejrut, Libanon, 1985) 1, 332, vidi, Sejjid Kutub, Fi zilalil-Kur'an, (U hladovima Kur'ana), (Daruš-šuruk, 1993), 1,77 .
} 
kazna bila primjerena i ekvivalentna tome. Pretvoreni su u majmune koji samo liče na ljude, a u biti nisu kao ljudi.

$\mathrm{S}$ druge strane, efekat griješenja se umnogostručava pomirenošću sa nekim grijehom koji se hilom „ušerijati” kao dozvoljeni čin. Na taj način se stvori običaj griješenja, što je najveće zlo.

Sličan primjer imamo i u predanju Ibnu Abbasa koje bilježi Ebu Davud, a Hakim i drugi ga smatraju vjerodostojnim. U njemu se kaže:

„Allah je prokleo židove! Bio im je zabranjen loj, a oni su ga prodavali i hranili se time. A kada Allah zabrani da se nešto jede, onda zabrani i korištenje njegovom prodajom."

\section{Šerijatska kazna za blud - istine i kontroverze}

Islam i njegov šerijatski sistem su posebno na meti zbog kazne bluda, tzv. kazne hadda (fiksirana kazna), koja je često predmet neopravdane kritike, averzije i totalnog nerazumijevanja, iako je Šerijat posvetio ovom pravnom problemu neprevaziđene, iznijansirane propise i prevenciju koji štite ljudsko društvo, pravdu pa i aktere samog ovog čina.

Treba imati u vidu da islam podstiče na ženidbu. U nekim slučajevima čak je strogo propisuje izričitom naredbom. Razlog je u tome što se smatra da je bračna zajednica apsolutno najbolji i najprirodniji put seksualnog zadovoljavanja i podizanja potomstva koje samo na takav način može u potpunosti doživjeti pravu ljubav majčinstva i očinstva i svega ostalog što podrazumijeva porodica. $\mathrm{S}$ tim u vezi islam je zabranio sve ono što je u koliziji i suprotnosti sa bračnom zajednicom ili što je može ugroziti i uništiti. Naredio je primjenu strogih normi oblačenja i ponašanja koje ničim ne potiču nemoral, nego upućuju na osnivanje bračne zajednice. Pošto je seksualni nagon jedan od najjačih nagona kod čovjeka, onda je Zakonodavac zabranio sve što bi moglo dovesti do njegovog nezakonitog ispoljavanja: 
Islam je dozvolio i ograničenu poligamiju, ne forsirajući je, kako čovjek u situaciji kada mu supruga ima mjesečnicu ili kada je u porođajnom čekanju, ne bi imao opravdanje za nemoral i preljubu.

Nemoral uzrokuje nebrojene probleme; svađe, pa čak i ubistva, a mnogi časni ljudi smatraju da sramotu toga čina ne može sprati ništa osim krvi. Razvod i razbijanje porodice, narušavanje rodbinskih i nasljednih veza, štete bračnim partnerima itd., samo su neki od rezultata ovoga poroka.

Zbog svega toga nemoral je u Šerijatu sankcioniran najstrožijom i najrigoroznijom kaznom hadda.

\section{Sankcija bluda je više preventivne nego retributivne prirode}

Prije sankcioniranja ovom na prvi pogled drastičnom kaznom moraju se preduzeti mjere predostrožnosti kojima će se potpuno eliminirati sumnje u izvršenje prijestupa, jer se hudud (fiksirane šerijatske kazne) ne provode u slučaju postojanja sumnje kod utvrđivanja činjeničkog stanja prijestupa zbog fikhskog pravila: „Kazne hududa (fiksirane sankcije od strane Zakonodavca) ne izvršavaju se u situaciji postojanja sumnje u delikt."

Iz preventivnih uvjeta koji se navode $\mathrm{u}$ islamskom pravu, a moraju se ispuniti da bi sankcija za ovaj čin bila pravovaljana, razumije se da je gotovo nemoguće njihovo praktično ispunjenje osim u slučaju priznanja i svjesne želje aktera ovog čina da dunjalučkom kaznom spere grijeh i spasi se eshatološke kazne. Zato je sankcija zinaluka više preventivne nego retributivne prirode.

Iz predostrožnosti čin zinaluka moraju posvjedočiti četiri muška svjedoka ${ }^{27}$, koji se konsenzusom izjašnjavaju da su vidjeli sami spolni čin. Hanefijska pravna škola definira spolni čin koji se sankcionira kaznom hadda da je to haram, zabranjeni seksualni

\footnotetext{
${ }^{26}$ Kur'an, 17, 32.

${ }^{27}$ Dakle, svjedočenje žena se ne uzima kao pravovaljano u ovom prijestupu, niti svjedočenje nepouzdanih, nepodobnih osoba, kao što ćemo vidjete kod uvjeta svjedočenja.
} 
kontakt (čin) sa poželjnom živom ženskom osobom koji se ostvari direktnim kontaktom s njenim spolnim organom, autonomijom volje partnera, dogodi u mjestu koje je pod pravednom jurisdikcijom islamske vlasti, izvrši od strane osoba koje su prihvatile Šerijat kao pravni poredak, gdje se ne radi o delikvenciji robinje ili sumnji da je robinja ili da se ne radi o delikvenciji žene u braku sa tom osobom ili se sumnja da je u braku sa njim... ${ }^{28}$

Tumačenjem ove opširne definicije hanefijske pravne škole može se reći da definicija zinaluka ne obuhvata:

- Čin harama koji izvrši maloljetnik, jer nije mukellef (adresat, pravni subjekt, obveznik) niti ludak iz istog razloga.

- Također, ni čin obavljen sa maloljetnom, ili mrtvom osobom, ili sa životinjom. To je vid perverzije koji se rjeđe događa i spada u drugu vrstu delikta.

- Ni čin koji se obavi u analni otvor žene ili muškarca. Ovaj čin se po Ebu Hanifi ne tretira zinalukom za razliku od ostalih imama (Malik, Ahmed i Šafija) kao i njegova dva učenika (Ebu Jusuf i Muhammed).

- Niti čin koji se obavi pod prisilom tako da se ne sankcionira kaznom hadda onaj koji je prisiljen na čin zinaluka. Postoji konsenzus da se silovana žena ne kažnjava tom kaznom. U slučaju prisile muškarca na čin zinaluka islamski pravnici su se razišli kod kvalifikacije ovog djela. Šafijska i malikijska pravna škola su na stanovištu da se prisiljeni muškarac ne kažnjava ni kaznom hadda niti kaznom ta'zira (nefiksirana, diskreciona kazna vladara, sudije). Hanbelije su na stanovištu da se prisiljeni muškarac kažnjava, jer erekcija, neophodna da bi se izvršio taj čin, upućuje na to da je „prisiljeni” imao želju kojoj je prisila samo isprika. Ebu Hanife se dvoumio kod ovog pitanja praveći razliku između prisile vladara i nekog drugog, dok konačno nije došao do rješenja smatrajući da problematična erekcija kod onoga koji se prisiljava na zinaluk ne mora biti izraz želje nego spolne moći.

\footnotetext{
${ }^{28}$ Vidi, Muhammed Emin poznat kao Ibni A'bidin, Hašijetu reddil-muhtar (Glosa odgovora zabludjelom), 4, 4, dr. Vehbe Ez-Zuhajli, El-FiKhul-islamijju ve edilletuh (Islamsko pravo i njegovi dokazi), (Darul-fikr, 1996), 6, 26,
} 
- Definicija podrazumijeva da se dotični čin tretira samo u islamskoj pravnoj državi gdje vlada zakon Šerijata.

- Također podrazumjeva da se odnosi samo na prijestupe muslimana i zimmija (ehlul-kitabije u islamskoj državi koji su u mirovnom sporzumu sa muslimanima).

Zadnji dio definicije onoga što se smatra zinalukom, koji se sankcionira kaznom hadda predmet je širokog komentara pravnih škola u islamu tako da ne vidimo potrebu da se sve to navodi.

Četverica svjedoka koji svjedoče zinaluk moraju konsenzusom potvrditi da su vidjeli čin zinaluka čiju smo definiciju naprijed elaborirali. Dakle, moraju posvjedočiti da su vidjeli vrh spolnog uda muškarca unutar spolnog organa žene. Snošaj i akt koji nije bio u spolni organ žene ne tretira se zinalukom koji se sankcionira kaznom hadda.

Ako makar jedan od četiri svjedoka dadne različitu izjavu, ili povuče izjavu, onda se kazna zinaluka poništava, a sudi svjedocima za potvoru. Ne treba ni naglašavati stroge uvjete koje moraju ispunjavati svjedoci, a o kojima ćemo govoriti poslije, da bi im se vjerovalo.

Zbog svega ovoga stroga kazna hadda je više da zastraši i djeluje preventivno, nego što ju je moguće dokazati i primijeniti na konkretnom slučaju.

Zinaluk može biti čin koji je izvršila oženjena ili neoženjena osoba. Razlikuje se sankcija za ženjenu i nevinu (neženjenu) osobu tako da imamo dva potpuno različita hadda, u zavisnosti od bračnog stanja prijestupnika delikta zinaluka. Naravno, to je predmet konsenzusa islamske uleme.

Zato je bez ikakvog pravnog uporišta u Šrijatu mišljenje haridžija $^{29}$ o jednakosti ove kazne za ženjene i neženjene osobe...

${ }^{29}$ Vidi, Muveffekud-din b. Kudame, El-Mukni' (Dostatan), u zbirci sa Eš-Šerhulkebir i El-Insaf, (Izdanje kralja Fehda, Hidžr, 1966), 26, 237,

Muhammed b. Ahmed b. Rušd El-Kurtubi, Bidajetul- mudžtehid ve nihajetulmuktesid (Početak mudžtehida i kraj umjerenog), (Darul-kutubil-i'lmijje, Bejrut, Liban, 1988), 2, 434. 
Dakle, u zavisnosti od bračnog stanja prijestupnika (po konsenzusu islamskih pravnika), imamo dva hadda, tj. dvije kategorije sankcije za prijestup zinaluka:

\section{1) Kazna neženjene osobe (haddul-bikr) za nemoral}

Postoji konsenzus islamskih pravnika da je sankcija za zinaluk neženjene, odnosno neženjene muške ili ženske osobe, stotinu udaraca $^{30}$, kako je propisano kur'anskom normom:

„Bludnicu i bludnika izbičujte sa stotinu udara biča, svakog od njih, i neka vas pri vršenju Allahovih propisa ne obuzima prema njima nikakvo sažaljenje." 31

\footnotetext{
${ }^{30}$ Vidi, Burhanud-din, Ebul-Hasen El-Marginani, El-Hidaje šerh bidajetil-mubteda (Uputa, komentar početog početka), 2, 97,

Zafer Ahmed El-U'smani, I'laus-sunen (Uzdizanje sunneta), (Idaretul-Kur'ani velu'lumul-islamijje, Karači, Pakistan, 1415. h.),11, 468,

Ibrahim b. Muhammed El-Halebi, Multekal-ebhur (Sastajalište mora), (Muessesetur-risale, 1989), 1, 331,

Muhammed Emin, poznat kao Ibni A'bidin, Hašijetu reddil-muhtar (Glosa odgovora zabludjelom), 4, 13,

Šemsud-din Muhammed A'refe Ed-Dusuki, Hašijetud-Dusuki a'leš-Šerhil-kebir (Glosa Dusukija na Veliki komentar), (Darul-fikr,), 4, 319,

Muhammed b. Ahmed b. Rušd El-Kurtubi, Bidajetul- mudžtehid ve nihajetulmuktesid (Početak mudžtehida i kraj umjerenog), (Darul-kutubil-i'lmijje, Bejrut, Liban, 1988), 2, 434,

Muhammed b. A'li Eš-Ševkani, Nejlul-evtar (Postizanje ciljeva), (Darul-džil, Bejrut, Libanon, 1973), 7, 249,

Muhammed Eš-Širbin El-Hatib, Mugnil-muhtaď̌ (Onaj koji obogaćuje potrebnog), (Darut-turasil-A'rebi, Bejrut, Libanon,1958), 4, 144,

Ebu Zekerijja Muhjud-din b. Šeref En-Nevevi, El-Medžmu'u šerhul-muhezzeb ( Zbirka stilizovanog komentara), (Darul-fikr), 20, 7,

Muveffekud-din b.Kudame, El-Mugni (Onaj koji obogaćuje), tahkik (identifikacija): dr. Abdul-Muhsin Et-Turki i dr. Abdul-Fettah El-Hilv, (1992), 12, 322,

Muveffekud-din b. Kudame, El-Mukni' (Dostatan), u zbirci sa Eš-Šerhul-kebir i ElInsaf, (Izdanje kralja Fehda, Hidžr, 1966), 26, 254,

dr. Vehbe Ez-Zuhajli, El-FiKhul-islamijju ve edilletuh (Islamsko pravo i njegovi dokazi), (Darul-fikr, 1996), 6, 23/28

vidi, Sejjid Sabik, Fikhus-sunne (Islamsko pravo u sunnetu), (Darul-fikr, Bejrut, 1977), 2, 344.

${ }^{31}$ Kur'an, 24, 2.
} 
Međutim, pravnici su se razišli u tome da li se ovoj kazni dodaje kazna protjerivanja od godinu dana.

Šafija i Ahmed su mišljenja da se ovoj kazni pridodaje i kazna protjerivanja od godinu dana. Oni temelje svoje mišljenje na predanju koje bilježe Buharija i Muslim, od Ebu Hurejre i Zejda b. Halida, a u kojem Poslanik, a.s. presuđuje u slučaju čovjeka koji ga obavještava da je njegov sin radeći kao nadničar učinio zinaluk sa ženom svoga poslodavca: „,Tvome sinu kazna je stotinu udaraca uz protjerivanje godinu dana! A ti Unejs, odi do te žene, pa ako prizna, kamenujte je!'

Otišli su kod nje i ona je priznala. Poslanik, a.s., je naredio da se kamenuje."

Buharija bilježi od Ebu Hurejre da je Poslanik, a.s., dosudio kaznu hadda i protjerivanje iz mjesta boravka na period od godinu dana u slučaju zinaluka neženjene osobe.

Historijska je činjenica da su tu kaznu primjenjivale pravedne halife bez ikakvog prigovora i otpora od strane ashaba. Ebu Bekr je protjerivao u Fedek, Omer u Siriju, Osman u Egipat, a Alija u Basru.

Malik smatra da se kazna protjerivanja odnosi samo na delikventa muškarca, a ne na ženu.

Mišljenje Ebu Hanife je da se kazni hadda od stotinu udaraca ne pridodaje i kazna protjerivanja, osim u slučaju ako sudija smatra da tako treba postupiti. Dakle, u slučaju kad sudija smatra da je to neophodno, ima diskreciono pravo da odmjeri i kaznu protjerivanja. ${ }^{32}$

\section{2) Sankcija ženjene osobe (haddul-muhsan) za nemoral}

Kazna za zinaluk oženjene ili ženjene, odnosno udate ili udavane osobe je po konsenzusu islamskih pravnika redžm (kamenovanje) $)^{33}$.

\footnotetext{
32 Vidi, Ibrahim b. Muhammed El-Halebi, Multekal-ebhur (Sastajalište mora), (Muessesetur-risale, 1989), 1,331.

${ }^{33}$ Vidi, Burhanud-din, Ebul-Hasen El-Marginani, El-Hidaje šerh bidajetil-mubteda (Uputa, komentar početog početka), 2, 96,

Zafer Ahmed El-U'smani, I'laus-sunen (Uzdizanje sunneta), (Idaretul-Kur'ani velu'lumul-islamijje, Karači, Pakistan, 1415. h.),11, 468,
} 
Ovaj termin spomenut je u Kur'anu isključivo u značenju ubijanja kamenovanjem ${ }^{34}$.

U predanju „muttefekun a'lejhi” (zabilježen od strane dva najpouzdanija sabirača hadisa, Buharije i Muslima) od Ebu Hurejre prenosi se da je Allahov Poslanik, a.s., rekao:

„Neki čovjek došao je Poslaniku, a.s., u džamiju, pozvao ga i rekao mu: ,Učinio sam zinaluk.' Poslanik, a.s., se okrenuo od njega. On je to ponovio četiri puta. Nakon njegovog četverestrukog priznanja Poslanik, a.s. ga priziva k sebi i pita: ,Jesi li ti lud?' ,Ne!' odgovori ovaj. ,A jesi li se ženio?' ,Da.” Onda je Poslanik, a.s., rekao: ,Vodite ga i kamenujte!' Prenosi se da je Džabir b. Abdullah bio u grupi koja je izvršila kamenovanje. On pripovijeda: ,Bio sam u grupi koja ga je kamenovala. Obavili smo to na musalli (veliki prostor koji se koristi za klanjanje bajrama). Međutim, kada ga je pogodilo prvo kamenje, pobjegao je. Stigli smo ga na Harri i dovršili kamenovanje."

Hadiski autoriteti bilježe predanje u kojem Omer kaže:

Ibrahim b. Muhammed El-Halebi, Multekal-ebhur (Sastajalište mora), (Muessesetur-risale, 1989), 1, 330,

Muhammed Emin poznat kao Ibni A'bidin, Hašijetu reddil-muhtar (Glosa odgovora zabludjelom), 4, 10,

Šemsud-din Muhammed A'refe Ed-Dusuki, Hašijetud-Dusuki a'leš-Šerhil-kebir (Glosa Dusukija na Veliki komentar), (Darul-fikr), 4, 319,

Muhammed b. Ahmed b. Rušd El-Kurtubi, Bidajetul- mudžtehid ve nihajetulmuktesid (Početak mudžtehida i kraj umjerenog), (Darul-kutubil-i'lmijje, Bejrut, Liban, 1988), 2, 434,

Muhammed b. A'li Eš-Ševkani, Nejlul-evtar (Postizanje ciljeva), (Darul-džil, Bejrut, Libanon, 1973), 7, 249,

Muhammed ĚšŠirbin El-Hatib, Mugnil-muhtadž (Onaj koji obogaćuje potrebnog), (Darut-turasil-A'rebi, Bejrut, Libanon,1958), 4, 146,

Ebu Zekerijja Muhjud-din b. Šeref En-Nevevi, El-Medžmu'u šerhul-muhezzeb ( Zbirka stilizovanog komentara), (Darul-fikr), 20, 8,

Muveffekud-din b.Kudame, El-Mugni (Onaj koji obogaćuje), tahkik (identifikacija): dr. Abdul-Muhsin Et-Turki i dr. Abdul-Fettah El-Hilv, (1992), 12, 309,

Muveffekud-din b. Kudame, El-Mukni' (Dostatan), u zbirci sa Eš-Šerhul-kebir i ElInsaf, (Izdanje kralja Fehda, Hidžr, 1966), 26, 237,

dr. Vehbe Ez-Zuhajli, El-FiKhul-islamijju ve edilletuh (Islamsko pravo i njegovi dokazi), (Darul-fikr, 1996), 6, 40,

Sejjid Sabik, Fikhus-sunne (Islamsko pravo u sunnetu), (Darul-fikr, Bejrut, 1977), 2,346 .

${ }^{34}$ Kur'an, 11, 91, vidi, 19, 46, vidi, 36, 18, itd. 
„Poslaniku, a.s., objavljen je ajet redžma (kamenovanje), božanska norma koju smo naučili i razumjeli. Poslanik, a.s., prakticirao je kamenovanje, a i mi poslije njega."

To što se desila lingvistička derogacija ove norme koju spominje Omer pa je nemamo u Kur'anu, ne upućuje a priori na to da se desila i derogacija propisa kako neki hoće da predstave ovaj slučaj.

Da bi se neko mogao pravno tretirati muhsan (ženjen ili oženjen, odnosno udana ili udavana) i da shodno tome podliježe kazni redžma, mora ispunjavati slijedeće uvjete:

- Da je mukellef (obveznik, adresat). Ako se radi o djetetu ili ludaku ne tretira se pravno mukellefom.

- Da je slobodan. Robinja, analogno njoj i rob, imaju drugu vrstu kazne po kur'anskoj normi u kojoj se kaže: „A kada one kao udate (robinje) počine blud, neka se kazne polovicom kazne propisane za slobodne žene" 35 Naravno, kamenovanje podrazumijeva smrtnu kaznu koja se ne može podijeliti na polovicu tako da se njihova kazna odmjeri ta'zirom (diskreciona kazna sudije).

- Da je imao spolni odnos u prvovaljanom braku, pa makar i bez snošaja. Snošaj koji se obavi u pravno ništavom braku, pravno se ne tretira spolnim odnosom. Pušćenac i pušćenica računaju se muhsanom (ženjen, udavana).

Kazna hadda se primjenjuje nad muslimanima, zimmijama (ehlul-kitabijama u islamskoj državi) te nad muslimanima koji su murtedi (vjero-odstupnici ili počinioci apostazije). Ebu Hanife i neki drugi pravnici smatraju da se bičevanje primjenjuje i nad nemuslimanima, ali redžm (kamenovanje) samo nad muslimanima, pošto je kod njih islam uvjet za tretiranje muhsan (ženjen/udavana) kategorije delikventa.

Da bi kazna hadda bila izvršna delikvent mora ispunjavati slijedeće uvjete:

1. da je mentalno zdrav (pametan, normalan),

2. da je punoljetan,

3. da je čin zinaluka izvršio autonomijom volje (svojevoljno) i

4. da je znao za zabranu toga čina.

${ }^{35}$ Ibid, 4, 25. 
Fiksirana kazna hadda se dokazuje:

a) priznanjem ili

b) svjedočenjem.

\section{a) Fiksirana kazna (hadd) za nemoral po priznanju}

Priznanje je, kako ga tretiraju neki pravnici, tzv. kralj dokaza kod dokazivanja prijestupa. Historijski su poznati slučajevi da je Poslanik, a.s., presudio na temelju priznanja, kao što je bio slučaj sa Gamidijom i slučaj sa Mai'zom koji su svjedočili protiv samih sebe. To nije sporno ni kod jednog imama mezheba. Međutim, oni se razilaze samo po pitanju koliko puta treba priznati na temelju čega bi se mogla donijeti presuda za kaznu hadda. Malik, Šafija, Davud i drugi smatraju da je dovoljno samo jedno priznanje.

Hanefijska pravna škola na stanovištu je da su potrebna četiri priznanja u različitim prilikama i mjestima, dok Ahmed smatra da je dovoljno priznanje četiri puta uzastopce.

Preferira se prvo mišljenje zbog predanja koje smo ranije naveli, a u kojem se spominje da Poslanik, a.s., izvršava kaznu nad nemoralnom, udatom ženom, ne uvjetujući ponavljanje priznanja, kada naređuje: „A ti, Unejs, odi do te žene, pa ako prizna, kamenujte je!' Otišli su kod nje i ona je priznala. Poslanik, a.s., je naredio da se kamenuje."

Poništavanje priznanja o učinjenom deliktu zinaluka uvjetuje i poništavanje kazne kod hanefija, šafija i imama Ahmeda, zbog predanja koje bilježe Ahmed i Tirmizija od Ebu Hurejre, a u kojem se kaže „da je Ma'iz nakon što je zasut kišom kamenja pokušao pobjeći. Naletio je na čovjeka koji je bio naoružan košću od vilice deve kojom ga je udario. I ostali su pritekli i ubili ga. Spomenuli su to Poslaniku, a.s., koji reče: ,Što ga ne ostaviste?!"”

U drugoj verziji ovog predanja koje bilježe Ebu Davud i Nesaija od Džabira kazuje se da je Ma'iz nakon što je zasut kišom kamenja zavapio: ,Ljudi, vratite me Allahovom Poslaniku, a.s. Ubija me moj narod. Mene su obmanuli. Bio sam obaviješten da će me pogubiti Allahov Poslanik, a.s.!' 
Ne ostavismo ga dok ga ne ubismo. Kada smo se vratili Allahovom Poslaniku, a.s., i obavijestili ga o slučaju, rekao je: ,A što ga ne ostaviste i ne dovedoste meni?!'”

Ako muški partner prizna zinaluk, spominjući ženu s kojom je to uradio, a ona zaniječe, onda se kazna izvršava samo nad njim, kao što je bio slučaj zabilježen od strane Ahmeda i Ebu Davuda u predanju od Sehla b. Se'ida ,koji pripovijeda da je neki čovjek došao Allahovom Poslaniku, a.s., priznajući delikt zinaluka sa određenom ženom. Poslanik, a.s., je poslao po nju pitajući je za prijestup. Zanijekala je, pa ju je ostavio, a nad čovjekom, koji je priznao delikt zinaluka, izvršio je kaznu hadda."

\section{b) Fiksirana kazna (hadd) za nemoral po svjedočenju}

Optužba za zinaluk ima neobično teške posljedice za ženu i muškarca, njihovu porodicu i potomstvo. Zbog toga islam postavlja posebne uvjete za onoga ko svjedoči o ovom deliktu. Uvjeti su:

\section{1) Da budu četverica svjedoka}

$\mathrm{Za}$ razliku od svjedočenja u drugim predmetima, za ovaj prijestup se uvjetuju četiri svjedoka. U Kur'anu se kaže:,,Kad neka od žena vaših blud počini, zatražite da to protiv njih četverica od vas posvjedoče...,"36

\section{2) Islam}

To je uvjet po konsenzusu islamskih pravnika, svejedno radilo se o delikventu muslimanu ili nemuslimanu.

\section{3) Podobnost, pravednost, poštenje}

U Kur'anu se kaže: „I kao svjedoke dvojicu vaših pravednih ljudi uzmite." 37

\section{4) Punoljetstvo}

U Kur'anu se kaže da kada se govori o svjedocima, moraju biti: „dva muškarca vaša”. Ovaj izraz lingvistički podrazumijeva punoljetnu osobu. Poslanik, a.s., je rekao: „Ne pišu se djela trojici:

\footnotetext{
${ }^{36}$ Kur'an, 4, 15.

${ }^{37}$ Ibid, $65,2$.
} 
djetetu, dok ne postane punoljetno, spavaču, dok se ne probudi, i ludaku, dok ne postane pametan, normalan."

\section{5) Mentalno zdravlje (pamet)}

To se razumije i iz citiranog hadisa.

\section{6) Sigurno viđenje čina zinaluka}

Ovdje se radi o definitivnoj sigurnosti da se vidio čin zinaluka, odnosno da se vidio spolni ud muškarca u spolnom organu žene.

\section{7) Jasna izjava o zinaluku}

U ovom slučaju se ne primaju dvosmislene ili metaforičke izjave.

\section{8) Zajednička izjava}

Džumhur (izrazita većina) islamskih pravnika smatra da optužba i svjedočenje o zinaluku moraju biti zajednički od strane sva četiri svjedoka $u$ isto vrijeme i na jednom mjestu. Ako bi svjedoci došli ponaosob, onda se, po džumhuru, njihovo svjedočenje ne prihvata.

\section{9) Muškost}

Svi svjedoci moraju biti muškarci, osim po Ibni Hazmu koji dozvoljava da dvije žene mogu zamijeniti po jednog svjedoka muškarca, kao što je inače slučaj kod ostalih prijestupa i pravnih poslova.

\section{0) Da svjedočenje ne zastari}

Ovo je uvjet koji postavlja samo hanefijska pravna škola. Poznat je postupak Omera koji je rekao: „Oni koji svjedoče za kaznu hadda pa to ne učine odmah, u vrijeme samog čina, poslije se njihovo svjedočenje tretira da je iz pakosti i ne priznaje se."

Svjedok ima pravo svjedočiti, ali isto tako i prikriti sramotu delikta zinaluka. Ako odabere prikrivanje, zatim se poslije javi iz nekog svog razloga, kada slučaj zastari, to upućuje na zlobu i pakost, pa se ne prihvata. Hanefijski pravnici koji su postavili ovaj uvjet, nisu odredili vremenski period u kojem zastarijeva gonjenje za ovaj prijestup, nego su to ostavili kao diskreciono pravo sudiji koji vodi 
predmetni slučaj. Neki su, ipak, rekli da se taj period ograničava na mjesec dana, dok drugi zagovaraju period od šest mjeseci.

Naravno, bolest svjedoka i udaljenost od sudije može biti uzrokom da se kasni sa svjedočenjem i to opravdano ne zastarijeva.

Had (kazna) muhsana (ženjen/udavana) je kamenovanje delikventa do smrti na širokom praznom prostoru. Kamenovanje otpočinju svjedoci koji su ga prijavili i svjedočili da je počinio ovaj delikt. U slučaju da odbiju učestvovati u izvršenju kazne, da odsustvuju ili umru, obustavlja se kazna redžma (kamenovanje). Drugi koji otpočinje sa kamenovanjem je sudija, a potom i ostali ljudi koji se okupe zbog kazne. Kod onoga koji se kažnjava po priznanju, sudija otpočinje prvi sa kamenovanjem, pa potom i ostali ljudi ${ }^{38}$.

\section{Običaji i etno-sociološki aspekt nemorala}

Zanimljivo bi bilo pratiti ovu problematiku kroz etnosociološku prizmu, kroz običaje muslimana ovih područja i njihovu tradiciju.

Muslimanski narodni pripovjedač spominje prostituciju i blud (zinaluk) u muslimanskom društvu, ponekad, u kontekstu vladarskog zuluma (nepravda), kao u pjesmi „Razbolje se careviću Mujo” u kojoj se opisuje da je carević zatvorio Mahmut-pašinicu, tuđu ženu, i seksualno je iskorištavao, a njegov otac-car, u tome mu povlađuje i ne pušta je iz svoje kuće na traženje njenog zakonitog muža:

Oko bule čardak zatvorio,

Ljubio je tri bijela dana. ${ }^{39}$

A ponekad se spominje $u$ vidu opisa slučajeva nevjernih kaduna za čije će se nevjerstvo neminovno čuti. Narodna epika to naglašava htijući omraziti i pokuditi takav postupak koji će se razglasiti i počiniteljka će time, iako nastoji sakriti, svakako povući

38 Vidi, Ibrahim b. Muhammed El-Halebi, Multekal-ebhur (Sastajalište mora), (Muessesetur-risale, 1989), 1,330,

Burhanud-din, Ebul-Hasen El-Marginani, El-Hidaje šerh bidajetil-mubteda (Uputa, komentar početog početka), 2, 96,

${ }^{39}$ Nasko Frndić, Narodni humor i mudrost muslimana, (Stvarnost, 1972), 154. 
odgovarajuće konsekvence, kao što je opisano u pjesmi „Nevjerna kaduna":

Kad je večer o večeri bilo, Ide Ramo dvoru Ljubovića. Večeraše gospodske večere I svu mrklu noćcu prenoćiše; Al' kad jutro o zorici bilo, Progovara begova kaduna: „O svega ti, čelebija Ramo, Nemoj svojoj družbi kazivati, Gdje si bio, šta li si činio!" Ramo joj se kune i preklinje: „Neću, kado, života mi moga!" A u srcu šejtan mira ne da, Sve će reći čim družini dođe. ${ }^{40}$

Dakle, nezakonit čin bluda narodna epika je pokudila.

Fizički kontakt muškarca i žene dozvoljen je samo u validnoj bračnoj zajednici kao što se razumije iz stihova pjesme ,Malka Fata, ama plemenita":

„Da te mogu ufatiti, Fato, b'jelo bih ti lice obljubio, crne bih ti oči poposao, ruse bih ti kose pomrsio!" On mislio niko ga ne čuje, slušala ga malahna Fatima, pa govori Agu, momku mladu: „,Možeš, Ago, ako ti je drago, al' u tvome dvoru, a ne mome! Kad me vjenčaš, ljubi i obljubi.",41

U muslimanskom društvu, gdje su nastali ovi stihovi narodne epike, toliko se držalo do poštenja da je i sama sumnja, ili potvora

\footnotetext{
${ }^{40}$ Ibid, 176.

41 Munib Maglajlić, Antologija bošnjačke usmene lirike, (Alef, Izdavačka kuća Sarajevo), 123.
} 
Žene zbog bračnog nevjerstva bila dovoljan razlog njenog kažnjavanja, razvoda ili smrtne kazne, kao što se spominje u pjesmi „Alibegovica”:

Sve to sluša beže, Alibeže,

Od jada ga zaboljela glava;

Steže glavu srmali mahramom,

Pa on ide svom bijelu dvoru.

Susrete ga na avliji ljuba,

Da mu skine ćurak sa ramena.

Beg j' od sebe rukom otiskuje:

„,Bjež od mene, moja nevjernice",

Pa joj broji potpuno vjenčanje:

Trist' izbroji, trista se zabroji...42

U pjesmi „Vezak vezla Adem-kada” čak i neosnovana optužba i potvora snahe od strane svekrve da čini zinaluk sa mladim djeverom završava tragično za mladu, nevinu Adem-kadunu:

Vezak vezla Adem-kada, mlada nevjesta,

$\mathrm{Na}$ čardaku, na visoku džamli pendžeru,

Sav je đerđef pokapala groznim suzama.

Njoj dolazi Omer-beže, mlađi djevere,

$\mathrm{Pa}$ on pita mladu nevu, Adem-kadunu:

„Šta je tebi, Adem-kado, mlada nevjesto:

Sav si đerđef pokapala groznim suzama?"

Odgovara Adem-kada, mlada nevjesta:

„Prođi me se Omer-beže, mlađi djevere!

Tvoja majka, dobra žena, al' zlo govori:

Da ja ljubim tebe mlada, svoga djevera,

A Bog znade, i ti znadeš to bit' ne može!"

U to doba beg, Osman-beg, stiže na čardak,

Mestve skida, majku pita: ,Gdje mi je žena?"

,Eno ti je u halvatu, ne bilo ti je!

Ona ljubi Omer-bega, brata tvojega!"

Kad to čuo Osman-beže ode na čardak,

$\mathrm{Na}$ čardaku vjerna ljuba akšam klanjaše.

„,Brže ljubo, brže dušo, akšam predaji!"

Sablja sjeknu, ljuba jeknu, čedo proplaka!43

${ }^{42}$ Behar, list za pouku i zabavu, (Sarajevo, 1900/1), 37. 


\section{Običajni odnos društva prema nemoralu}

Muslimansko društvo bilo je veoma osjetljivo na nemoral i prostituciju. Mula Mustafa Bašeskija bilježi u svom Ljetopisu, koji je nastao u periodu od 1746. do1804. godine:

„Masa premlati dvije prostitutke, i to Travničku i Aginicu, a zatim ih protjeraju u Skopje.'

Za vanbračne odnose u narodnom pjesništvu predviđena kazna nije samo ovosvjetske prirode, nego se za takav čin prijeti i sa motivima eshatološkog, džehennemskog kažnjavanja:

Turundža je kraj dženneta rasla,

Na džehennem glavu naslonila,

Tu mi gore tri dobra junaka:

Jednom gore ruke do ramena,

Drugom gori obraz do očiju,

Trećem gore obje oči vrane.

Kome gore do ramena ruke,

On je bio svoju staru majku,

Kome gori obraz do očiju,

Ljubio je mlado nevjenčato,

Kome gore obje oči vrane,

Gledao je žene pod nićahom. ${ }^{45}$

U drugoj verziji ove pjesme daje se malo izmijenjeno obrazloženje kazni:

Kome gore ruke do lakata,

Grlio je mlado nevjenčato.

Kome gore noge do koljena,

On je iš'o varati djevojke.

Kome gore crne oči vrane,

Gledao je žene pod nićahom. ${ }^{46}$

${ }^{43}$ Munib Maglajlić, Antologija bošnjačke usmene lirike, (Alef, Izdavačka kuća Sarajevo, 1997), 169.

${ }^{44}$ Nasko Frndić, Narodni humor i mudrost muslimana, (Stvarnost, 1972), 383.

${ }^{45}$ Enver Mulahalilović, Vjerski običaji muslimana u Bosni i Hercegovini, (ElKalem, Sarajevo, 1989), 78.

${ }^{46}$ Ibid., 78. 
Vrhunac prezira, averzije i ogavnosti prema zinaluku iskazan je u pjesmi „Smrt Muje Hrnjice” u kojoj narodni pjevač spominje taj čin kao uzrok smrti Muje Hrnjice. Naime, narodna epika sa neskrivenim simpatijama i ljubavlju gleda na svoje narodne junake koje slika epskim nadljudskim osobinama. Smrt Muje Hrnjice narodni epičar ne može preboljeti da bude uzrokovana većim junaštvom od Mujina junaštva. Zato mu je namijenio uzrok smrti koji će biti toliko omražen od cjelokupnog javnog mnijenja da bi bio $u$ srazmjeri Mujine popularnosti kao narodnog junaka. U jednom prilično konfuznom opisu Mujo je predstavljen kao sihirbas koji iznevjerava povjerenje svoga pobratima i udara na čast njegove žene, zbog čega će ga ovaj ubiti.

Preljuba i nevjerstvo, plaća se, dakle, smrću u opisima narodnog stvaralaštva:

Kad iziđe na čardake Meho i pogleda crnijem očima, Mujo sjedi s ljubom na dušeku, Vino pije, a lišce joj ljubi.

Kad se Meho na avliju vrati, Kad to Mujo čeka na avliji, U ruci mu puška garabina. Tad pomisli Katarica Meho: „Ah li, Mujo, jedan sihirbazu, platićeš mi, boga mi jednoga..." 47 I on ubi buljugbašu Muju.

U pjesmi „Đerzelez Alija i Vuk Jajčanin” spominje se način kazne za preljubu:

Dvorbu hajduk Huseine dvori, Obdan pašu na kapiji dvori, A po noći pašinicu ljubi.

Vidjela ih Kumrija robinja, Pa je eto paši u odaju:

„Da vi’ ’̌, pašo, dugo jadan bio!

\footnotetext{
${ }^{47}$ Kosta Hörmann, Narodne pjesme muslimana u Bosni i Hercegovini, (Svjetlost, Sarajevo, drugo izdanje,1990), 276.

${ }^{48}$ Ibid. 278.
} 
U zao čas ga Husa nabavio,

Tebi mladu pašinicu ljubi."

Šut', robinjo, nemoj nikom kazat:

„Ja ću Husu posijeći glavu,

Pašinicu konj'ma na repove." 49

Iz prethodnih tekstova i motiva muslimanske narodne epike kristališe se običajno stajalište muslimanskog društva u našim krajevima spram nemorala kao i vremenski period primjene moralnih normi koje su se prakticirale, ne tako davno, u muslimanskom društvu. Nesporno je da su se ta pravna ponašanja i običaji ustalili i utemeljili konstantnom, sukcesivnom primjenom šerijatskih propisa.

Antun Hangi spominje moralnost i neporočnost muslimanskog društva, što je zapazio u vrijeme svoga službovanja po Bosni:

„Što moramo kod naših muslimana osobito istaknuti i pohvaliti, jest to da kod njih preljuba nema, niti ima slučajeva da bi muškarac u divljem braku živio. ${ }^{\mathbf{5 0}}$ Ja ne znam ni za jedan slučaj da je muslimanka rodila nezakonito dijete. Ta tu bi kamenovali. Zaista krasno!",51

Islamski običaji o kojima govori Hangi prakticirali su se u drugoj polovici devetnaestog vijeka. Međutim, nekoliko desetina godina kasnije, u izvještaju Muhameda Kantardžića o muslimanima na području Ulema medžlisa u Sarajevu podnesenom na Kongresu evropskih muslimana, spominje se statistički podatak da je ,u godini 1934. bilo...i 98 nezakonite novorođenčadi" ${ }^{, 52}$.

U Kalendaru iz 1938. g. navodi se da ,ukupan broj do sada prispjelih slučajeva konkubinata (divlji, nevjenčani brakovi) na

49 Đenana Buturović, Antologija bošnjačke usmene epike, (Alef, Izdavačka kuća Sarajevo, 1997), 73.

${ }^{50}$ Narodni, običajni izraz za vanbračnu zajednicu je ,divlji brak" kao što navodi i dr. Mehmed Begović, Porodično pravo, (Narodna knjiga, Beograd, 1961. Peto izdanje), 6.

${ }^{51}$ Običaji muslimana u BiH, (Svjetlost, Sarajevo, 1990), 184.

52 Vjersko-prosvjetne prilike muslimana u Bosni i Hercegovini, u: Glasnik Vrhovnog starješinstva Islamske vjerske zajednice Kraljevine Jugoslavije (Beograd) 10-11 (oktobar, novembar, 1935), 466. 
području Ulema medžlisa Sarajevo iznosi 271."53 Tu se navodi i podatak da ,u jednom naselju Bihaćkog okruga postoji 14 slučajeva konkubinata, od kojih njih nekoliko već duže vremena i sa velikim brojem djece. U svih 14 slučajeva žene su nemuslimanke."

Isti autor navodi $\mathrm{i}$ to da ,konkubinati kod muslimana, kod kojih su uslovi za rastavu braka daleko uprošteniji, nisu starijeg datuma i svaki takav slučaj smatran je prije dvadesetak godina rijetkim izuzetkom." 54

Dakle, kroz ove tekstove može se primijetiti pad morala kod bosanskih muslimana u novijoj historiji.

Naravno, Austro-ugarska okupacija Bosne 1878. g. imala je presudan utjecaj na pad moralnog ponašanja muslimana. Doduše, spomenuti slučajevi divljih brakova nisu bili klasični nemoralni čin prostitucije, nego, ili mješoviti brakovi, ili slučajevi koji u velikom postotku nisu imali pravni legalitet čiji su razlog razne poteškoće, tako da su to često bivali brakovi maltretiranih žena koje su bježale od prvog muža i ponovo se udavale bez čekanja da bi bile u kakvojtakvoj zaštiti od daljeg progona i maltretiranja, ili brakovi koji svoj pravni status bračnog ugovora ili razvoda nisu riješili zbog raznih administrativnih troškova, daća i sl. U slučajevima gdje je postojala pravna zainteresiranost političke i izvršne vlasti za rješavanje tih slučajeva velika većina ih se mogla riješiti na zakonski način sklapanjem legalnog braka (šerijatski sudovi su još uvijek bili u funkciji).

Također, veoma je zanimljivo spomenuti običaj koji se ustalio u okolici Prozora i dati njegovu šerijatsku elaboraciju.

Naime, pornografija i ekshibicionizam, uz sve ono što nose $u$ vidu moralne degradacije i pada moralnih vrijednosti, realnost su i našeg muslimansko-bošnjačkog društva. Međutim, korijeni ovog nemorala i njegova opravdanja počeli su ,hilama" šerijatskih pravnika koji su na takav način ohalaljivali haram.

53 Abduselam I. Balagija, Konkubinati (divlji brakovi) kod muslimana, Gajret, Kalendar za godinu 1938, (Sarajevo, 1937), 109.

${ }^{54}$ Ibid, 104. 
U „Glasniku Zemaljskog muzeja u Bosni i Hercegovini,"55 od davne 1894. godine čitamo o jednom nešerijatskom običaju u okolini Prozora utemeljenom na zabranjenoj hili koji pravno elaborira kadija Sadik ef. Ugljen navodeći: „Hajde zagji u naša sela, gdje žive sami muslimani, ili u ona, gdje su izmješani s kršćanima, pa će ti izmedju ostalog i to udariti u oči, da se u većine muslimanskih seljaka žene ne kriju ni od muslimana, niti od žitelja drugih vjera, nego žene njihove hodaju otkrivene kao i one drugih mileta, mada se to protivi islamu. Kada pomislimo, da se naši seljaci većim dijelom tvrdo drže vjere $\mathrm{i}$ njenih propisa, i da su seljaci uopće pobožniji od svoje braće varošana (šeherlija), to će nam onaka njihova navika svakako biti za čudo, zašto se seljak musliman (balija) u pogledu krijenja žene strogo ne drži šerijata".

Sadik ef. Ugljen će otkriti uzrok ovog neislamskog običaja u ,jednom starom običaju, koji na prvi pogled izlazi kao neka vrsta tajnog ropstva. Ovo umišljeno ropstvo dovodi muslimanski seljak u šerijat, te misli, da ovako protiv šerijata i ne griješi, kad mu se žena ne krije." 56 A radi se, naime, o tome da prilikom šerijatskog vjenčanja nakon sklapanja punovažnog bračnog ugovora, muž ili njegov zastupnik pokloni nešto novca mladi ili njenom zastupniku (osim mehra), što je u narodnom običaju trebalo značiti da je ta mlada kupljena kao robinja. Po Šerijatu robinja se ne mora oblačiti i kriti kao slobodna žena, tako da se i ove žene fiktivnog stanja ropstva poslije toga oblače isto kao i robinje, odnosno otkrivaju pred strancima.

Sadik ef. dalje analizira ovaj slučaj i navodi da je „teško iznaći odakle i kakvim se načinom ovaj običaj uvukao u glavu našeg seljaka”, ostavljajući vještijem peru „da istražuje njegov izvor”.

Međutim, sa izvjesnom sigurnošću može se utvrditi da je izvor ovom običaju u činjenici da se na ovim prostorima primjenjivao hanefijski mezheb koji je sadržavao i neka pravna rješenja utemeljena na pravnim lukavštinama, hilama.

Tako se neki „poznavalac šerijatskog prava” našao da primijeni hilu kod ovog slučaja da bi na takav način „ušerijatio”

${ }^{55}$ Vidi, Sadik ef. Ugljen, Čudnovati običaj u muslomanskih seljaka oko Prozora, u: Glasnik Zemaljskog muzeja u Bosni i Hercegovini, VI, (Sarajevo, 1894), 802. ${ }^{56}$ Ibid. 
nepokrivanje žene muslimanke primjenjujući propis o pokrivanju robinja na slobodnim ženama hilom fiktivne običajne prodaje slobodne žene, što je nespojivo sa Šerijatom koji je dokinuo sve vidove ropstva osim u slučaju ratnih zarobljenika. Zato, slobodna žena, ni de fakto ni de jure, ne može fiktivnom prodajom prilikom svoje udaje postati robinja, niti se na slobodnoj ženi mogu primjenjivati propisi ropstva.

Današnji rezultati i plodovi ove hile ${ }^{57}$, koja je „ušerijaćena” prije stotinjak godina i ustrojena kao lokalni običaj spomenut i zabilježen u okolici Konjica, imamo na ulici u vidu javnog nemorala, pornografije, ekshibicionizma i zastražujućeg pada morala.

\section{Zaključci}

1. Kur'an je osnovni izvor Šerijata a njegove norme, ibadeti (obredosovlje) imaju svevremenu aktualnost, svrhovitost, mudrost i nadnaravan božanski karakter. Sve ibadetske aktivnosti nekom svojom funkcijom služe za dobrobit čovjeka da bi ga fizički i duhovno održale $\mathrm{u}$ životu na dunjaluku, spasile na ahiretu i bile orjentir jednog normalnog uravnoteženog načina života.

2. Pojavom islama revolucionarno je promijenjen i poboljšan status žene u dotašnjim vladajućim pravnim običajima jer islam vrednuje ženu kao „najveće i najvrednije dunjalučko blago" što je revolucionarni napredak u tretmanu žene; daje joj se pravo vlasništva $\mathrm{i}$ nasljeđivanja i one se u tom smislu izravnavaju sa muškarcima pa čak dobivaju i diskreciono pravo mehra, kao nagradu ili jedan vid materijalne sigurnosti ulaska u brak dok ove vrijednosti nisu poznavali mnogi pravni sistemi ni hiljadu godina poslije pojave islama. Tako je bilo stanje i sa našim krajevima.

3. U savremeno doba ustrojavaju se nova zakonska rješenja koja uvode zemlje kao što su Njemačka i Italija a s kojima se hoće suzbiti seksualno uznemiravanje žena i mobing u savremenom društvu i radnom okruženju, ali ta zakonska rješenja kao da su prepisana iz normi Kur'ana. Dakle zakonodavstvo najvećih ekonomskih zapadnih

\footnotetext{
${ }^{57}$ Naravno uz političke i društvene činioce koji su imali i jači utjecaj i efekat na tu promjenu.
} 
sila kaskaju za Kur'anom preko 1400 godina i ne samo u vremenskom i historijskom smislu nego i suštinski. Iz razloga što neodoljivo podsjećaju na spomenute norme i propise izvedene iz svetih tekstova Kur'ana ali u smislu adresata kojima se upućuju odnose se samo na radno okruženje i zaštitu žena, kao ,slabijeg spola" na poslu. Dakle, radi se samo o ograničenom, jednostranom rješenju i pokušaju zaštite samo ženske populacije i samo u radnom okruženju gdje je žena najznezaštićenija. $U$ isto vrijeme slaba tačka ovih zakonodavstava $u$ rješavanju ovog problema je i u tome što ne propisuju pokrivanje kao sredstvo koje može pridonijeti zaštiti nego dozvoljavju otkrivanje i pokazivanje djelova tjela što je eksplicitni ,poziv" na mobing i uznemiravanje. Nasuprot toga kur'anske norme su općenite i ne ograničavaju se samo na poslovno okruženje nego obuhvataju društvo u svim njegovim sferama i djelatnostima, i ne samo da se odnose na zaštitu ženske nego i muške populacije, kao što se razumije iz spomenutih kur'anskih normi, pa čak rješavaju odnose roditelja i njihove djece unutar njihovih porodičnih stanova.

4. Iz svega ovog proizilazi da su islam kao vjera-religija i Šerijat kao njegov pravni sistem nadnaravnog, božanskog karaktera. Ta karakteristika ih odlikuje nad svim ostalim ljudskim sistemima $\mathrm{i}$ porecima. To je najbolji mogući sistem življenja za čovjeka u vremenskom totalitetu dunjaluka $\mathrm{i}$ ahireta.

5. Neke aspekte nemorala naglasio je Allahov Poslanik, a.s, kroz hadis kao vid predskazanja koje se ostvarivalo kroz historiju i ostvaruje se u našem vremenu ali se ostvaruje i navještena kazna iz pomenutog hadisa i kur'anskih kazivanja o ranijim narodima. Hadis baca težište na dvije bitne stvari iz kojih proizilazi i ovosvjetska $\mathrm{i}$ onosvjetska kazna a to su:

- pregonjenje u griješenju do razvrata i

- javno ponavljanje grijeha.

6. Javno, kolektivno upražnjavanje zabranjenih radnji povlači i kolektivnu ovosvjetsku kaznu kao što Kur'an obavještava u primjerima ranijih drevnih naroda $\mathrm{i}$ raznovrsnih kazni koje su ih zadesile zbog njihovih grijeha i neposluha. Narod Ada kaznio je i uništio „vjetrom ledenim, silovitim”, narod Semuda „glasom strahovitim”, narod Nuha „potopom” općim, narod Luta „kišom grumenja od pečena blata koje je neprekidno sipalo obilježeno od 
Gospodara tvoga" narod Šu'ajba ,glasom užasnim” itd. Njegova kazna nije bila nepravedna prema njima nego u srazmjeri sa grijehom koji su neprestano javno činili. Jevreji su doživjeli za jedan, također, poseban, jedinstven način griješenja tj. pokušaja hile, nadmudrivanja Allaha, dž.š, i izigravanja Njegovih propisa, egzemplarnu i drakonsku kaznu pretvaranja u majmune.

7. Problematiku bluda i nemorala može se pratiti i kroz etnosociološku prizmu, kroz običaje muslimana naših područja i njihovu usmenu i pisanu tradiciju zbog toga što je Muslimansko društvo bilo veoma osjetljivo na nemoral i prostituciju a njihova pravna ponašanja i običaji ustalili i utemeljili konstantnom, sukcesivnom primjenom šerijatskih propisa.. Mula Mustafa Bašeskija bilježio je neka običajna kaznena reagovanja u svom Ljetopisu koji je nastao u periodu od 1746. do1804. g. Za vanbračne odnose u narodnom pjesništvu kazna nije samo ovosvjetske prirode, nego se za takav čin prijeti i sa motivima eshatološkog, džehennemskog kažnjavanja.

Iz tekstova i motiva muslimanske narodne epike kristališe se običajno stajalište muslimanskog društva u našim krajevima spram nemorala kao i vremenski period primjene moralnih normi koje su se prakticirale, ne tako davno, u muslimanskom društvu.

\section{Literatura}

1. Kur'an,

2. Tefsir Ibn Kesir, skraćeno izdanje, Muhammed Nesib ErRifa'i, (Sarajevo, 2000)

3. Vojislav Spaić, Nasljednopravni običaji u BiH nakon AustroUgarske okupacije, Akademija nauka i umjetnosti BiH, knjiga XXXII., Odjeljenje društvenih nauka, knjiga 11., Sarajevo, 1967.

4. Dnevni Avaz 28 februara 2008.

5. Zekijjud-din El-Munziri, Et-Tergibu vet-terhibu minelhadisiš-šerif (Stimuliranje i zastrašivanje kroz hadis Allahovog Poslanika a.s.), (Muessesetut-tarih vet-turasil-arebi, 1968)

6. Nacionalni tjednik, Globus, br:702, 21/05/2004. 
7. Spolne bolesti od dr. Muhammeda Ali El-Barra u izdanju Visokog saudijskog komiteta za pomoć BiH, Sarajevo 1998.

8. dr. Muhammed Revas Kal'atdži, dr. Hamid Sadik Kanibi, Mu'džemu lugatil-fukaha'i, a'rebi- inklizi (Arapsko-engleska enciklopedija šerijatsko-pravne terminologije), (Darun-nefais, 1985)

9. Muhammed b. Ahmed El-Kurtubi, El-Džamiu' liahkjamilKur'an, (Zbornik propisa Kur'ana), (Daru ihjait-turasil-Arebi, Bejrut, Libanon, 1985)

10. Muhammed Nesib Er-Rifa'i, Tejsirul-Alijjil-kadir lihtisari tefsir Ibn Kesir, (Olakšavanje Uzvišenog-Moćnog u sižeiranju komentara Ibn Kesira), (Bejrut, 1978)

11. Sejjid Kutub, Fi zilalil-Kur'an, (U hladovima Kur'ana), (Daruš-šuruk, 1993)

12. Muhammed Emin poznat kao Ibni A'bidin, Hašijetu reddilmuhtar (Glosa odgovora zabludjelom)

13. dr. Vehbe Ez-Zuhajli, El-Fikhul-islamijju ve edilletuh (Islamsko pravo i njegovi dokazi), (Darul-fikr, 1996)

14. Muveffekud-din b. Kudame, El-Mukni' (Dostatan), u zbirci sa Eš-Šerhul-kebir i El-Insaf, (Izdanje kralja Fehda, Hidžr, 1966)

15. Muhammed b. Ahmed b. Rušd El-Kurtubi, Bidajetulmudžtehid ve nihajetul-muktesid (Početak mudžtehida i kraj umjerenog), (Darul-kutubil-i'lmijje, Bejrut, Liban, 1988)

16. Burhanud-din, Ebul-Hasen El-Marginani, El-Hidaje šerh bidajetil-mubteda (Uputa, komentar početog početka)

17. Zafer Ahmed El-U'smani, I'laus-sunen (Uzdizanje sunneta), (Idaretul-Kur'ani vel-u'lumul-islamijje, Karači, Pakistan, 1415. h.)

18. Ibrahim b. Muhammed El-Halebi, Multekal-ebhur (Sastajalište mora), (Muessesetur-risale, 1989)

19. Muhammed Emin, poznat kao Ibni A’bidin, Hašijetu reddilmuhtar (Glosa odgovora zabludjelom)

20. Šemsud-din Muhammed A'refe Ed-Dusuki, Hašijetud-Dusuki a'leš-Šerhil-kebir (Glosa Dusukija na Veliki komentar), (Darul-fikr,)

21. Muhammed b. A'li Eš-Ševkani, Nejlul-evtar (Postizanje ciljeva), (Darul-džil, Bejrut, Libanon, 1973) 
22. Muhammed Eš-Širbin El-Hatib, Mugnil-muhtadž (Onaj koji obogaćuje potrebnog), (Darut-turasil-A'rebi, Bejrut, Libanon,1958)

23. Ebu Zekerijja Muhjud-din b. Šeref En-Nevevi, El-Medžmu'u šerhul-muhezzeb ( Zbirka stilizovanog komentara), (Darulfikr)

24. Muveffekud-din b.Kudame, El-Mugni (Onaj koji obogaćuje), tahkik (identifikacija): dr. Abdul-Muhsin Et-Turki i dr. AbdulFettah El-Hilv, (1992)

25. Sejjid Sabik, Fikhus-sunne (Islamsko pravo u sunnetu), (Darul-fikr, Bejrut, 1977)

26. Nasko Frndić, Narodni humor $i$ mudrost muslimana, (Stvarnost, 1972)

27. Munib Maglajlić, Antologija bošnjačke usmene lirike, (Alef, izdavačka kuća Sarajevo)

28. Behar, list za pouku i zabavu, (Sarajevo, 1900/1)

29. Enver Mulahalilović, Vjerski običaji muslimana u Bosni $i$ Hercegovini, (El-Kalem, Sarajevo, 1989)

30. Kosta Hörmann, Narodne pjesme muslimana u Bosni $i$ Hercegovini, (Svjetlost, Sarajevo, drugo izdanje,1990)

31. Đenana Buturović, Antologija bošnjačke usmene epike, (Alef, izdavačka kuća Sarajevo, 1997)

32. dr. Mehmed Begović, Porodično pravo, (Narodna knjiga, Beograd, 1961, peto izdanje)

33. Običaji muslimana u BiH, (Svjetlost, Sarajevo, 1990)

34. Glasnik Vrhovnog starješinstva islamske vjerske zajednice Kraljevine Jugoslavije (Beograd) 10-11 (oktobar, novembar, 1935)

35. Gajret, Kalendar za godinu 1938, (Sarajevo, 1937)

36. Glasnik zemaljskog muzeja u Bosni i Hercegovini, VI, (Sarajevo, 1894) 
PROF.DR MUHAREM ŠTULANOVIĆ, P.H.D.

\section{WOMAN AND IMMORALITY IN SHARIAH, WITH AN ETHNO-SOCIOLOGICAL RETROSPECTIVE}

\section{SUMMARY}

Qur'an as Allah's final Revelation to mankind is of such content that it testifies with its numerous miracles, divinity and superiority that it comes from the Almighty and Allknowing Allah. No one except Allah was able to write it. Qur'anic miracles and wonders never cease, even the modern science is amazed by the beauty of Allah's Book. Qur'an represents a scientific miracle because numerous information from it was confirmed by the modern scientific researches and various experiments.

This supernatural dimension of the Holy Qur'an has received special attention since the year 1400 after Hijra or since the year 1979, when an assembly was founded as a part of a University in the Kingdom of Saudi Arabia. The basic intention of this assembly is to research and explore the scientific miracle of the Qur'an.

Concidering the fact that the Qur'an is the fundamental source of Islamic law, its ibadah (rituals), norms and standards have constant value, purpose, wisdom and supernatural divine character. All of the proscribed ibadahs bring benefit to humans in order to give a mental and phisical support in this life, salvation in the next life and are used as a landmark of a normal, fullfilled and balanced existence.

Appearance of Islam has changed and improved the status women had in earlier customary law because Islam considers a woman to be a ", most precious and most valuable belonging in this world." This represents a revolutionary improvement of womens status, giving her the right of property and inheritance which gives women equality with men, and even giving women a discretional right of mehr. Mehr represents form of a reward or one aspect of financial security before marriage and as such gives evidence or excellence of divine Shariah system.

In modern times several countries such as Germany and Italy apply newly founded law solutions in order to surpress sexual 
harassment and mobing in modern societies and work enviroment.These laws have enormous similarity to the principles found in the Holy Qur'an, meaning that the legislation of the most advanced contemporarry countries is inferior to Islamic law.

Several aspects of immoral behaviour were indicated by Allah's Messenger, peace and blessings of Allah be upon him, in a form of prophecy which has been realized throughout periods of time and which fulfilment we testify in our contemporariness.

Islam and his judicial system are being critisized because of the prescribed penalty for adultery, so-called " hadd sanction „, (fixed sanction) which is often a subject of unjustified criticism, aversion and a complete misunderstanding, although Shariah dedicated to this specific law problem unexcellable decrees and prevention which protect human societies, justice as well as the participants in this act. This penalty in Islamic law is more of a preventive than retributive nature. Problem of adultery can also be wieved from etno-sociological aspect, through cumstoms of Bosnian Muslims and their tradition.

We can conclude that Islam as a religion and Shariah as judicial system are of a divine, supernatural character. This characteristic distinguishes them from the all man made systems. It is the best possible life system for humans in this and the next life. 
أ. أ.د. محرم شتو لانوفيتش

المرأة والفساد الخلقي في الثريعة الإسلامية مع التفات قومي واجتماعي

\section{خلاصة البحث}

إنّ آخر خطاب الله للناس المتمثّل في القرآن الكريم يشهد بإعجازه وخوارقه في أصغر سورة أحستة

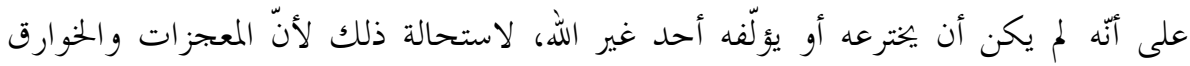

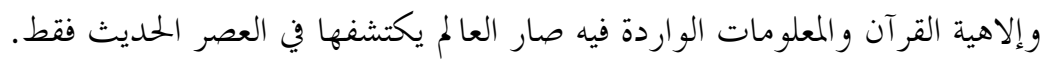

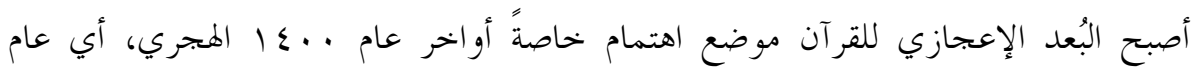

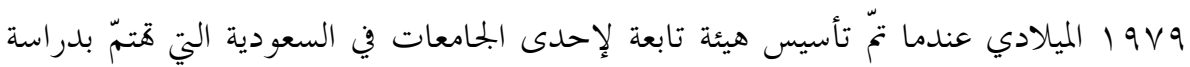
القر آن العلمية.

مما أنّ القرآن مصدر أساسي للشريعة الإسلامية فإنّ أحكامه وعباداته لها صلاحية لكل زمان،

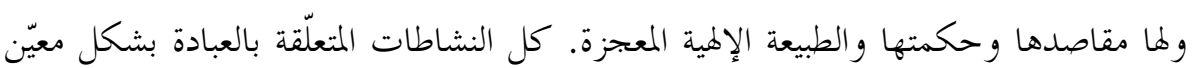

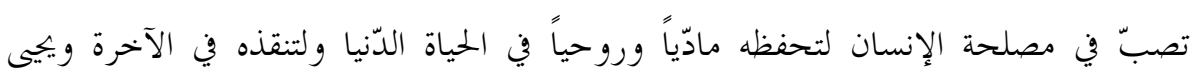
الإنسان حياة طبيعية متوازنة.

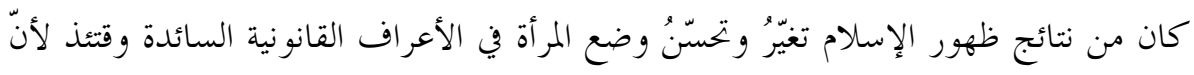

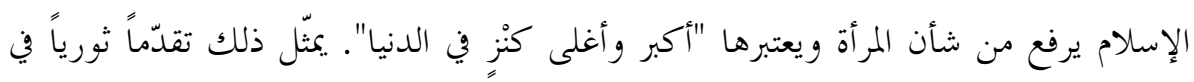

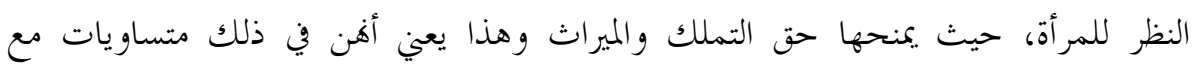

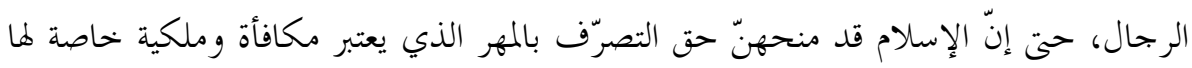

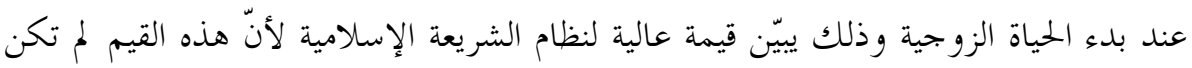

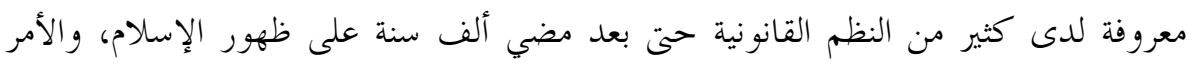
نفسه ينطبق على بلادنا.

تظهر المعلومات في العصر الحاضر في الدول مثل ألمانيا وإيطاليا عن بعض الحلول القانونية الجديدة المتعلقة بردع التحرش الجنسي للنساء في البحتمع المعاصر والمحيط الوظيفي وكأنّ تلك فيك

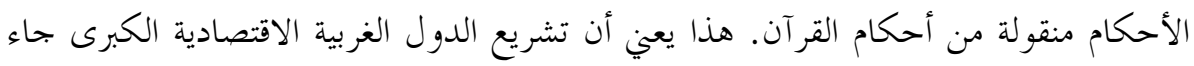

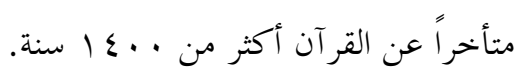


لقد حذّر البيُ صلى الله عليه وسلّم من بعض نواحي الفساد الخلقي في حديثه كنوع من التنبأ

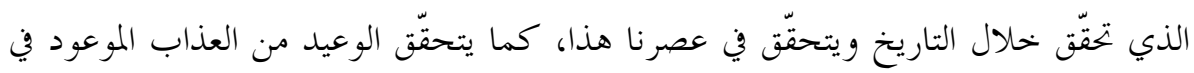
الحديث المذكور والقصص القر آنية عن الأمم السابقة.

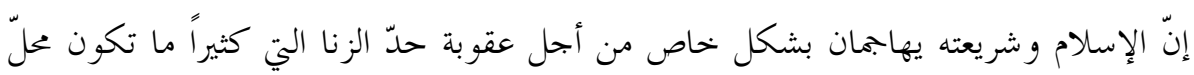

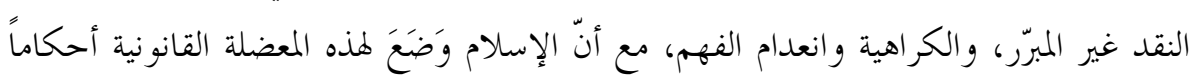

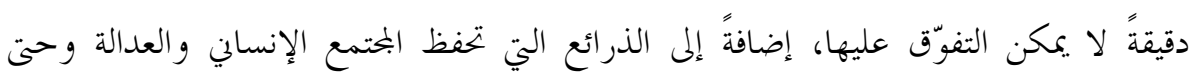

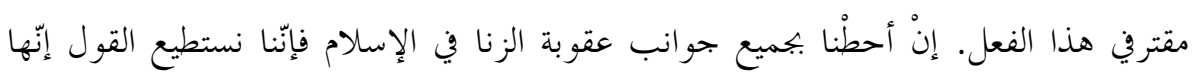

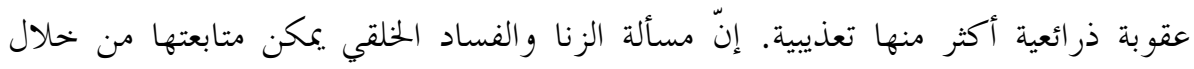
منظور القومية والاجتماعية ومن خلال عادات وتقاليد مسلمي هذه المناطق.

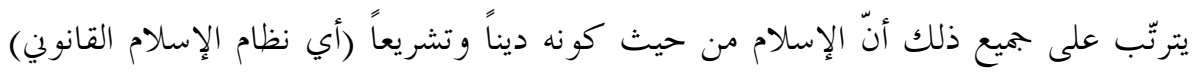

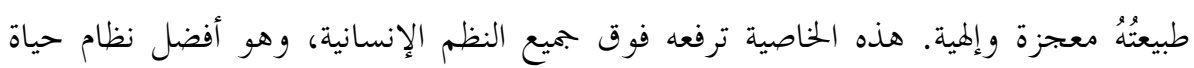
لإإنسان في الدنيا والآخرة. 